\title{
Taha Hussein and Abbas Mahmud al-Aqqad on the Greek Philosophy: A Comparative Study
}

\author{
Nabil Fouly \\ International Islamic University of Islamabad, Pakistan \\ email:n_fouly@yahoo.com
}

\begin{abstract}
Taha Hussein (1889-1973) and Abbas Mahmud al-Aqqad (1889-1964) are two prominent contemporary scholars in Egypt. This article delivered the comparison of both thoughts regarding to the Greek philosophy, while extensively influenced by the Greek philosophical tradition with two different responses. Thaha Husein so fascinated to the Greek philosophical traditions in which he developed appreciatively as found on his works. While al-Aqqad, he almost concerned on reviewing the value of the Greek philosophical tradition. His interaction to them feels more rigid because he used to accentuate his Arabian color and manifested his resistence when interacting with the Greek philosophical tradition. On several occasions, Al-Aqqad more often criticized them as compared to Thaha Husain. Well-known as westernized, Thaha Husain, instead of being uncritical of Greek philosophy, to him, the beginning of Greek philosophy formulation somehow indicated through their interaction with the Eastern culture. As said, East in the past became a source and reference, albeit limited to the physical aspect. While al-Aqqad, he viewed uncertainly whether Greek or East is the major source of the early emergence of philosophy as a scientific tradition.
\end{abstract}

\section{Keywords:}

Greek Philosophy, Islamic Philosophy, West, East 
يكاد الرأي يستقر عند أكثر مؤرخي الفلسفة شرقا وغربا على أن اليونان هو النبع

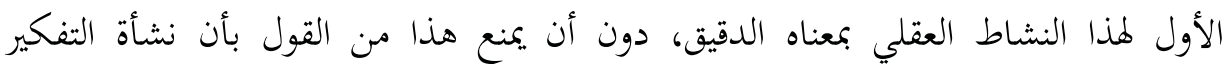

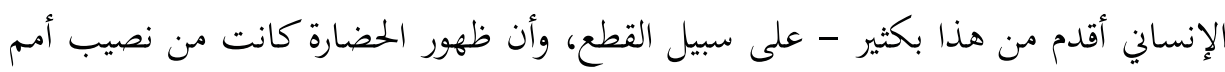
أخرى أعرق من اليونان وأسبق منها بدهور طويلة.

وإن كان هناك من يسعى من المؤرخين إلى نسبة نشوء الفلسفة إلى هذه الأمة الشرقية

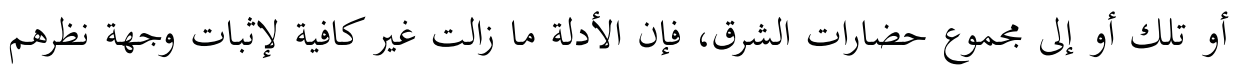
هذه، ما دمنا نعني الفلسفة بمعناها الخناص الذي يتناول التفكير في قضايا الوجود العامة

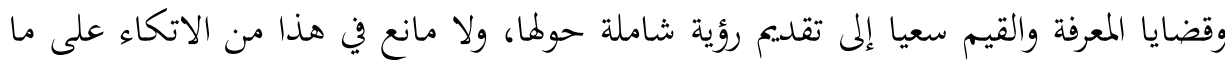
استقر في العرف الديني أو العلمي ما دام يحمل معه دليله الملائم (رسل، ترجمة: فؤاد زكريا

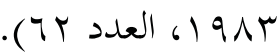
وأحسب أن هذه القضية - أي بدء ظهور الفلسفة- هي قضية تاريخية لن يجدي

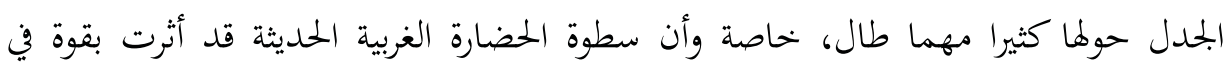
ابتحاهات الرأي المتعلقة بكثير من قضايا العلم والفكر وتاريخهما، ووجّهتها وجهة تنحاز غالبا إلى تلك الجهة من العالم، كما أن جانبا كبيرا من تراث البشرية ما زال مفقودا (جوتليب $\cdot\left(T+T^{\prime}, 1 \leq\right.$ وقد يكون أهمَّم من هذه القضية في درس التاريخ الفكري للإنسان أن ننزع الإطلاق

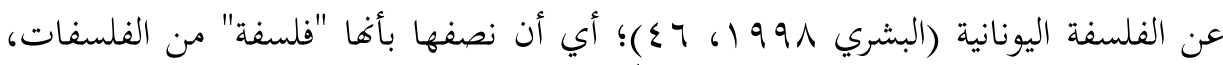
وليست هي "الفلسفة" بمعناها المطلق، ونعتبر الفلسفة نشاطا عقليا عاما له خصائصه التي يمكن أن تتحقق في أي عصر وأي بحتمع من بحتمعات البشر. ومن هنا سيرتفع الحظر الفقهي

DINIKA, Volume I, Number 3, September - December 2016 
الصارم الذي يقول به بعض المسلمين عن الفلسفة، كما ستصبح فلسفة اليونان جحدّة تاريخية للفلسفات الأخرى دون أن تكون مقياسا يقاس عليه غيرها. كما أن نزع الإطلاق عن فلسفة اليونان يتيح لنا أن نفهم الفكر منفصلا عن اللوازيه

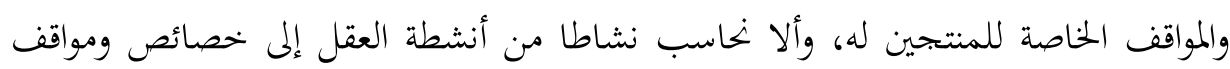
لبعض منتجيه، وإن كان هؤلاء المنتجون هم رواده الأولين، بل أكبر رموزه التاريخيين.

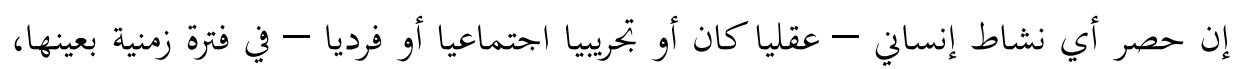

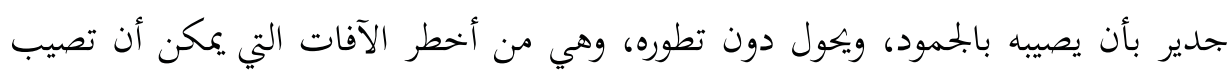
الفكر وأهله.

وإذا كان الموقف من فلسفة اليونان قد تنوع قديما وحديثا، شرقا وغربا، فإن للبحث في مواقف

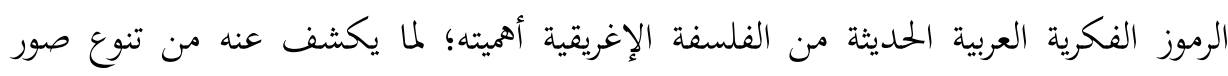

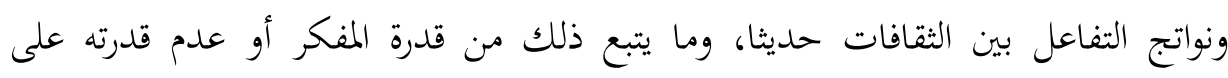
الاستقلال بمواقفه، والحفاظ على هويته أثناء الغوص في ثنقافات الآخرين.

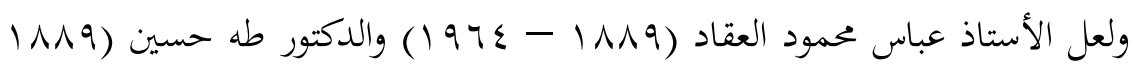

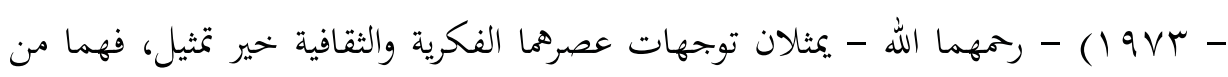
بناة الحياة الثقافية العربية في القرن العشرين، خاصة في نصفه الأول، شاركا في الحياة الأدبية والفكرية مشاركة كبيرة، وخاضا معارك واسعة حول مسائل في اللغة والأدب والفن والفكر فياه

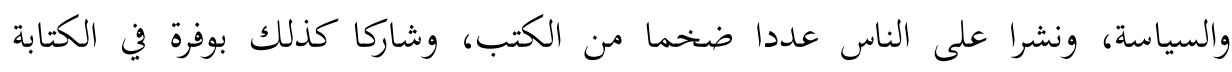
للصحافة.

وقد جمع الرجلان بقوة بين الثقافتين العربية والغربية، وأبديا وجهة نظرهما في حاضرهما

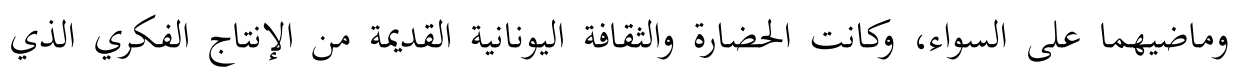


اهتم كلاهما ببيان موقفه منه اهتماما ظاهرا، وأباحا لنفسيهما الخوض في قضايا الفلسفة

الإغريقية، وتحدثا عن رجالاتما وآرائهم في مختلف قضايا الوجود والسياسة والمُتمع وغيرها. ولعل بعض القراء يتساءل: وما جدوى درس مثل هذه الآراء وقد بتحاوزها الزمن، فقد مضى عصر طه حسين والعقاد كليهما، وتقدمت الحياة بعدهما في كل بحالاتما تقدما هائلا في

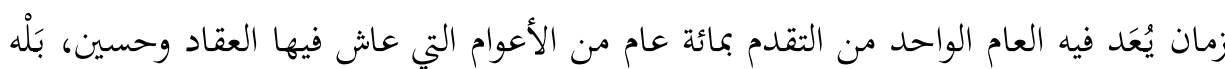
ما سبق ذلك؟!

والحقيقة أن طه حسين والعقاد ليسا منا ببعيدين في الزمان، وقد صارا نموذجين في الحياة الفكرية العربية أكثر منهما بحرد شخصين، كما أن تاريخ الفكر هو نفسه فكر؛ وذلك

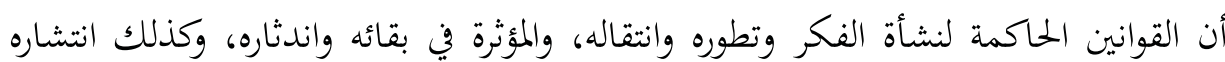
وانحساره - هي قوانين واحدة في كل زمان. كذلك فإن حاضر الفكر - والحياة عموما - لا يُفََمَم فهما دقيقا بدون فهم جذوره - خاصة القريب منها - فهما جيدا.

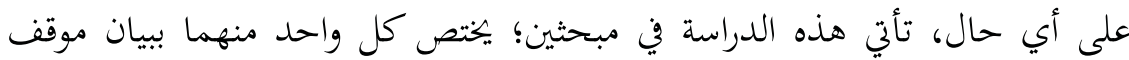

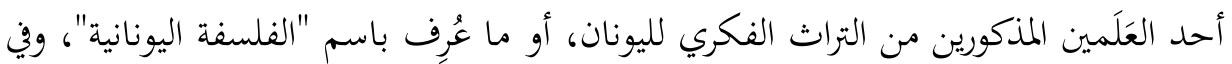
ثنايا ذلك أتعرض لبعض المقارنات بين الآراء والمواقف الفكرية التي ذهبا إليها، مع محاولة تقديم تفسير لها كلما أمكن.

\section{المبحث الأول: موقف طه حسين من الفكر اليوناني}

قبل الخوض في بيان عناصر هذا الموقف، أرى من المناسب أن أشير على عجل إلى طبيعة التكوين الثقافي لطه حسين على شهرته بين الدارسين، توسلا من هذا إلى تقديم تفسير للمواقف التي سيبديها من الفكر والحضارة اليونانية.

DINIKA, Volume I, Number 3, September - December 2016 
إننا يمكن أن نلخص ثقافة طه حسين بأها كانت مزيجا متصارعا من الجحديد والقديم، ومما هو شرقي وما هو غربي، إلا أن القديم الشرقي - وأعني به الثقافة الإسلامية خحاصة -

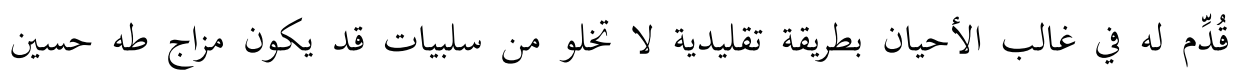

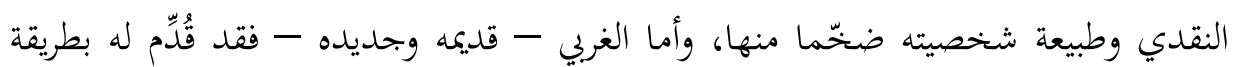
أكثر حداثة، وأكثر مراعاة لحق الطالب في أن يفهم ويناقش بلا إهانة ولا تعدٍ من المعلمين

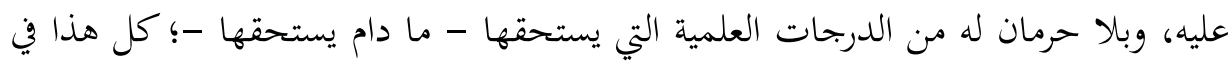
ظروف متناقضة يبدو فيها الميزان الحضاري للغرب راجحا جدا مقارنة بالوضع العام للمسلمين.

ومن هنا ظهر الرجل الجامع بين الثقافتين الإسلامية والغربية أكثر ميلا إلى الغرب

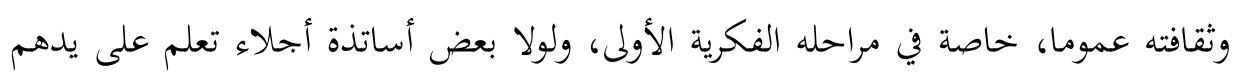
علوم الإسلام والعربية في الأزهر والجحامعة المصرية (ذكر منهم في "الأيام": الشيخ عبد الله دراز، والشيخ سيد المرصفي، والشيخ محمد بخيت، والأستاذ حفني ناصف، والأستاذ إسماعيل

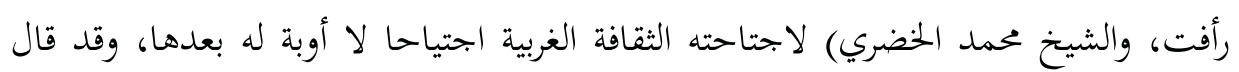

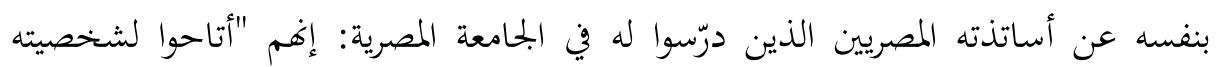

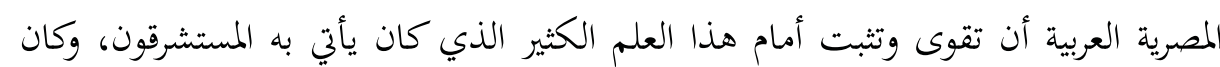

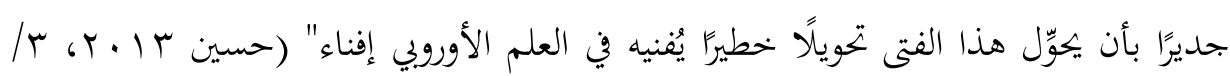

لقد بقي هذا الازدواج الثقافي جزءا أساسيا من شخصية طه حسين الذي كان ينغر من

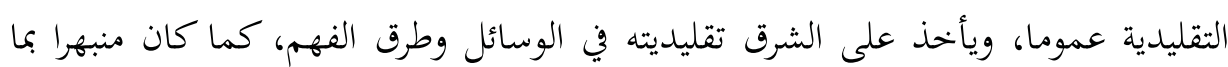
حققه الغرب من تفوق حضاري، ونتج عن هذا صراع مستمر في عقل الأديب والأكاديمي 
"الأزهري السوربوني" بين فكرتين تتفقان قليلا وتختلفان كثيرا، فماذا يمكن أن يكون موقفه من الفلسفة والفكر اليوناني باعتباره منتجا غربيا وعريقا في الوقت نفسه؟

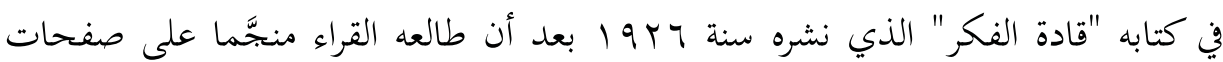

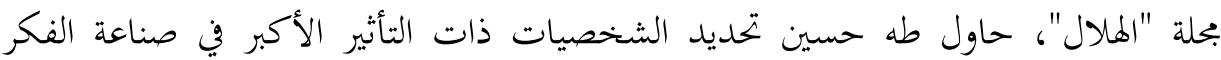
الإنساني في عوالم الأدب والفلسفة والسياسة منذ أقدم العصور، فمنح اليونان النصيب الأكبر

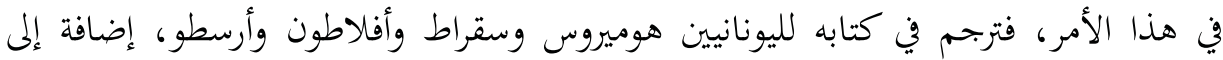

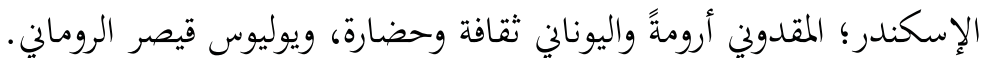

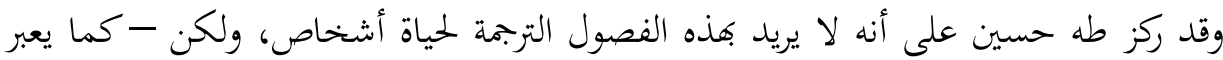
- "لتاريخ العقل الإنساني، وما اعترضه من ضروب التطور وألوان الاستحالة (= التحول)

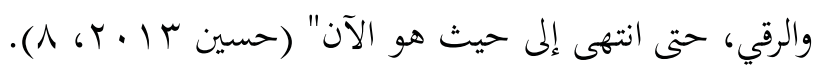

وحين ننظر إلى هذه الخطة التأليفية وإلى الأسماء التي تناول طه حسين دورها في صناعة التهاع

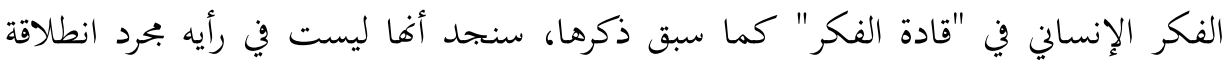

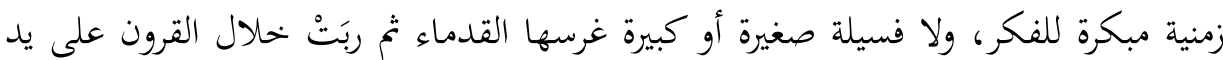
خلفائهم المتتابعين من مختلف الأمم، ولكنها تحديد لاتحاهات الفكر فيما تلا في العالم كله،

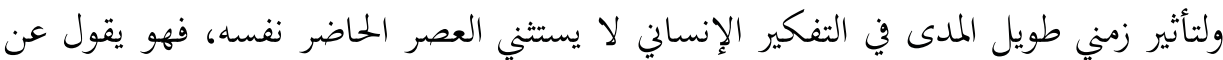

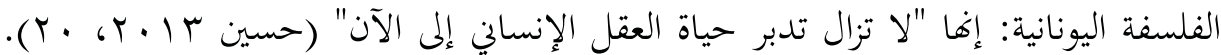

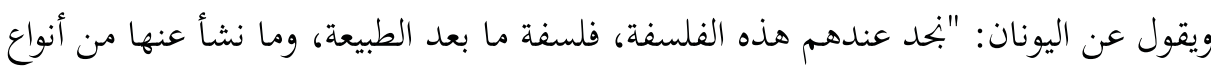

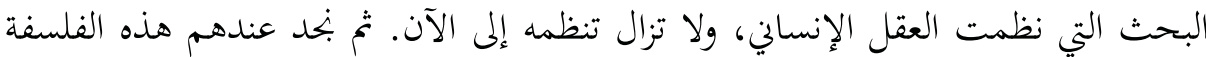

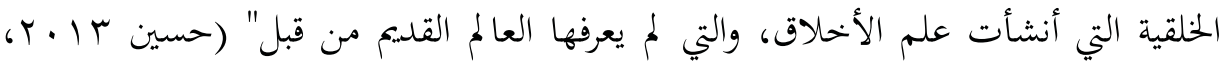


وبند كذلك بيانا لرأي طه حسين في الفلسفة اليونانية وتأثيرها في العالم الإسلامي في

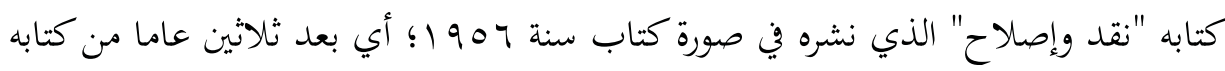

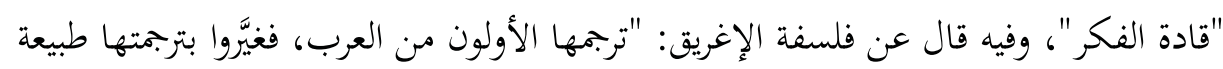

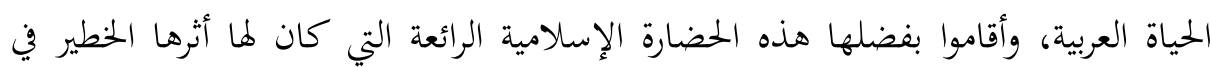

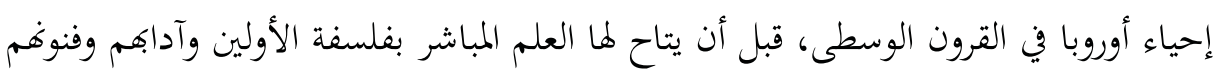

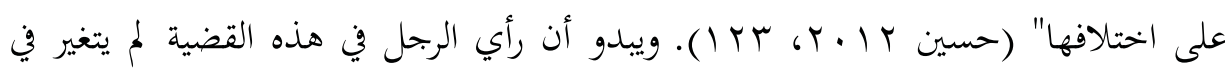

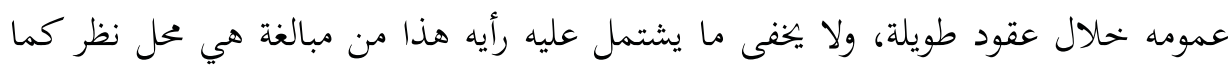
سيأتي قريبا.

\section{رأيه في أسباب نشأة الفلسفة في اليونان}

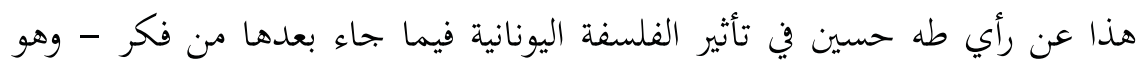

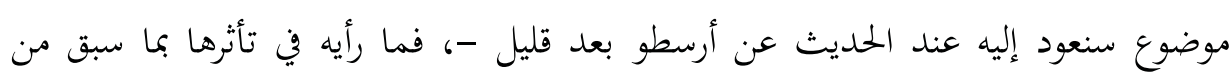

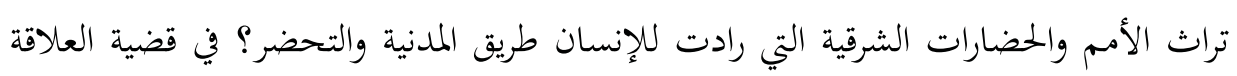

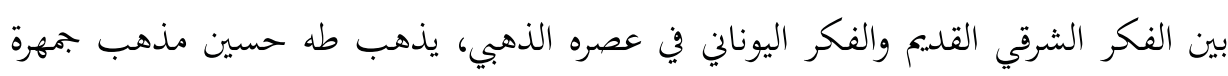

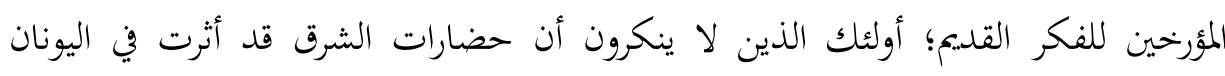

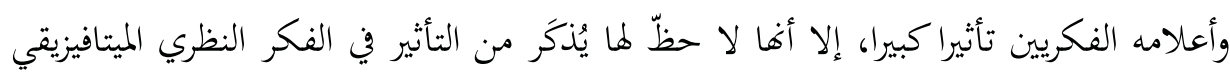

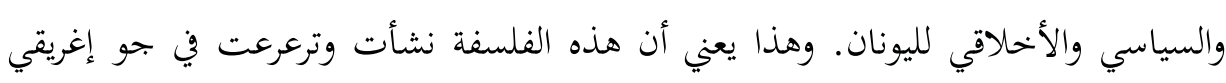

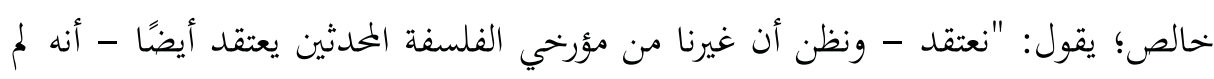

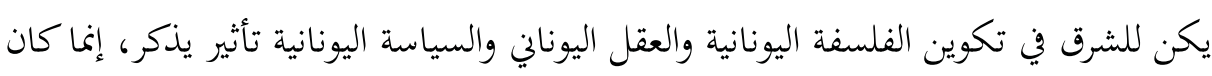

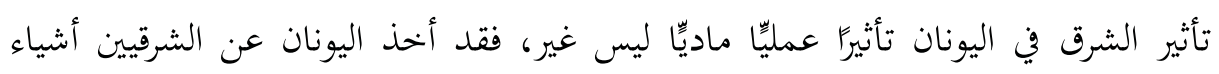

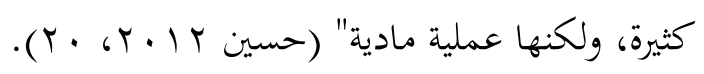


والحق أنه لا أحد من الباحثين المنصفين يمكنه أن ينكر قيمة الفلسفة اليونانية، ولا

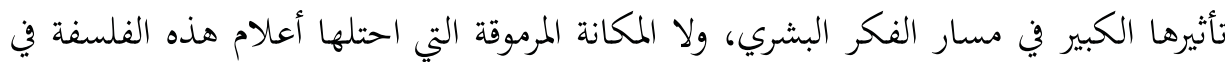

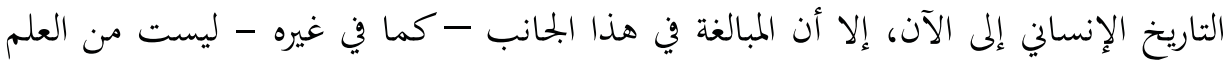

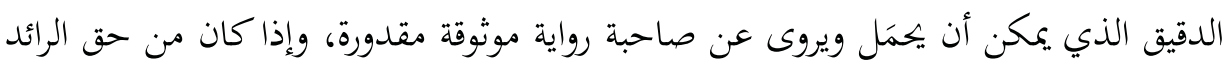

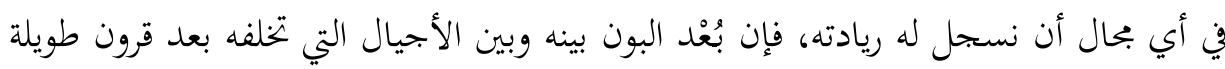
وسط أجواء فكرية وحضارية خختلفة ينبغي وضعه في الاعتبار عند تقييم تأثير هذا الرائد ودوره.

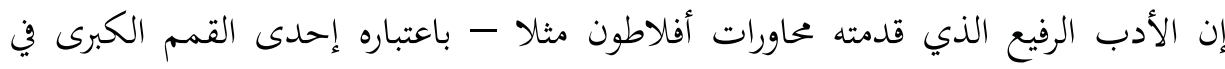

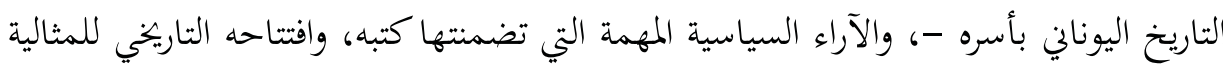

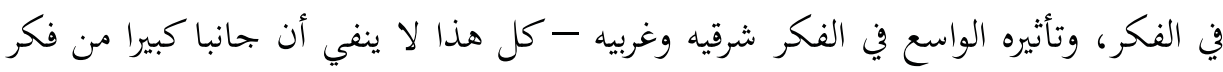

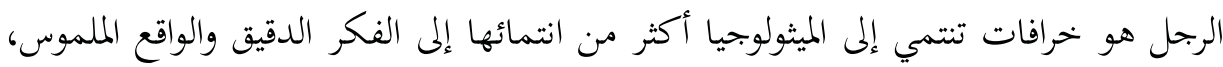

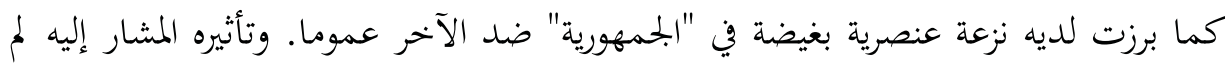

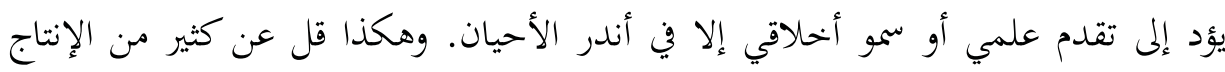

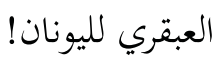

وفي محاولته لبيان الظروف التي أدت إلى نشأة الفلسفة في اليونان، يقول طه حسين عن

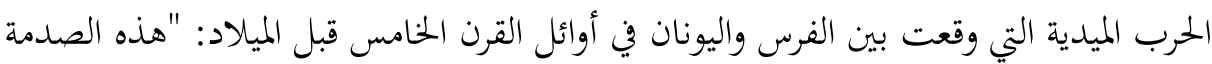

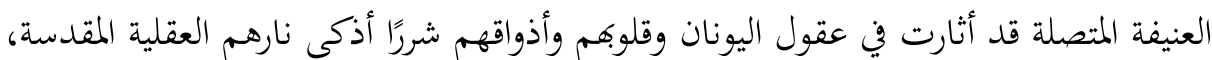

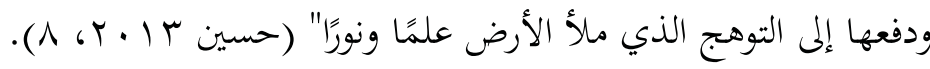

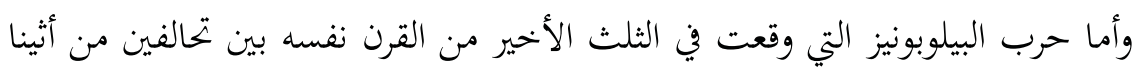

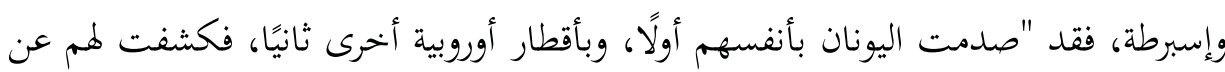

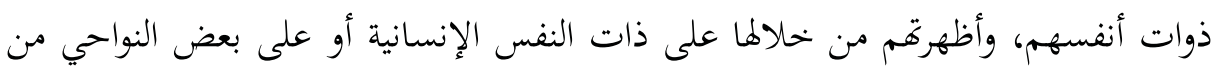

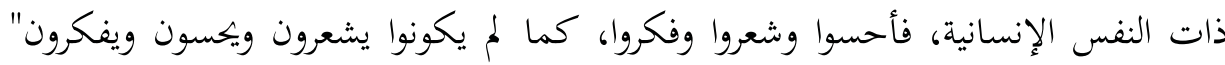

DINIKA, Volume I, Number 3, September - December 2016 
(حسين rا • ץ، م-9). ف "الهوَل الذي انتشر في بلاد اليونان بحكم هذه الحروب المتصلة قد

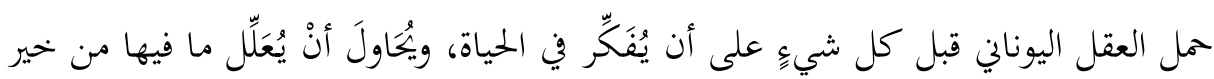

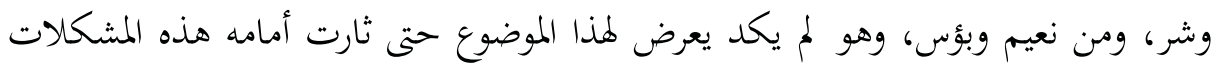

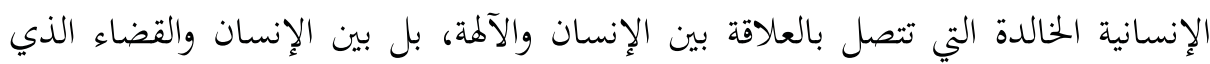

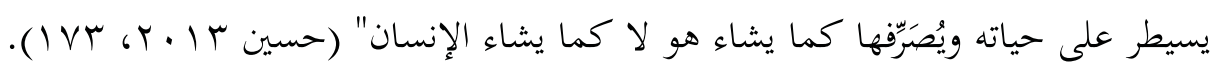

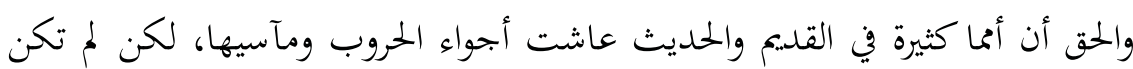
هذه الظروف دافعة وحدها إلى التفلسف في كل الأحوال، ومعنى هذا أن ظاهرة كبيرة مثل ظهور الفلسفة بمعناها المعروف في اليونان دون غيرها - حسب الشواهد التاريخية المتوفرة - هو أمر أكثر تعقيدا مما ذكره الدكتور طه حسين هنا، فقد تداخلت عوامل جغرافية واجتماعية ونفسية وسياسية كثيرة صنعت هذا القدر التاريخي، قد يكون منها حروب اليونان الأهلية والخارجية، لكنها تفاعلت معا في بجتمع ترتفع فيه نسبة القادرين على القراءة والكتابة، ويأحذ الشعر والأدب فيه موضعا خاصا يصنع عقلية اليوناني، كما طاف بعض أعلام التراث الفلسفي اليوناني الكبار وحصّلوا كثيرا من خبرات الأمم المحيطة.

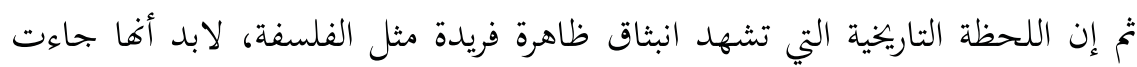

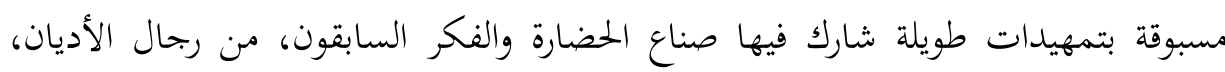
والشعوب القديمة المتحضرة، ومطزري الحياة البشرية بصورة أو أخرى.

\section{يقين تاريخي}

ومن الناحية التاريخية يتعامل طه حسين مع الفلسفة اليونانية وشخصياتما باعتبار أن وجودهم من اليقينيات الثابتة التي لا يدخلها الشك، فقد سجل مناظرة كان منبهرا بها دارت في أحد المؤتمرات الجامعة بين باحث فرنسي (لفيفر) وآخر بلجيكي (دوبريل) حول صحة 
وجود سقراط وجودا حقيقيا، حيث ذهب الباحث الأخير إلى أن سقراط بجرد خرافة، وأنه لا

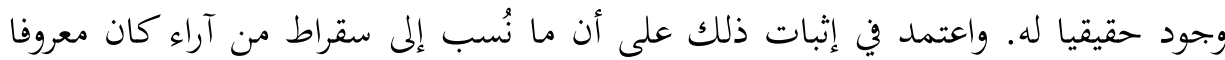
قبله، وأن سقراط ليست له صورة ولا شخصية واحدة، فقد بدا أحيانا نموذجا للعبث الفني في كتابات الأدباء، ثم تطور إلى شخصية جادة فَكِهة، ثم أصبح أبا للفلسفة ورمزا لها، مما يعني

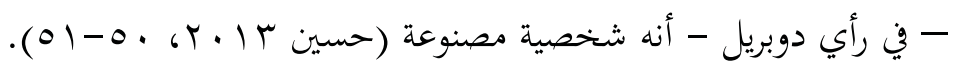
وقد ناقش طه حسين هذا الرأي بإنكار ودهشة كبيرة مستعينا - فيما يبدو من عباراته - بملاحظات لفيفر في دحضه، ورأى أن وجود الفيلسوف اليوناني بالتفاصيل المسرودة في الكتب عن حياته وشخصيته هي محل إجماع، وأن دوبريل عالج القضية علاجا فلسفيا، وكان

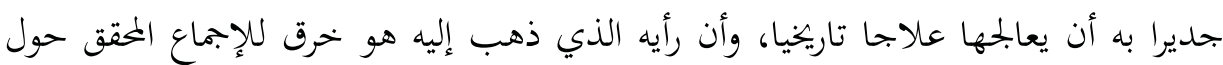
وجود سقراط؛ ذلك "أننا - كما يقول - إذا استبحنا لأنفسنا الشك من غير حساب، لم

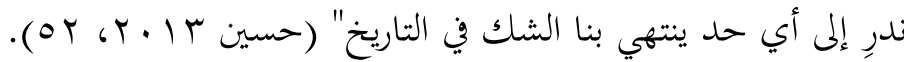
ولا شك أن التوسع في الشك بهذه الصورة ينافي المنهج العلمي الدقيق بحق، إلا أن

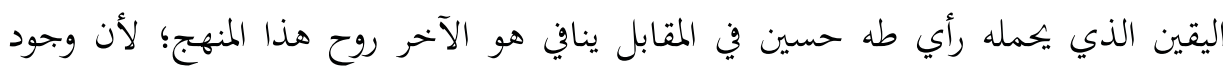
شخصية سقراط إنما نستدل عليه بمجموعة من القرائن تصل بالكاد إلى درجة الرجحان، وأما القطع والقول بالإجماع الذي لا يخرمه إلا شذوذ دوبريل فهو من المحازفات غير الدقيقة.

\section{تقليد الفلسفة اليونانية على بصيرة}

بنى طه حسين رؤيته في وجوب العودة إلى التاريخ لفهم ثقافة المصريين - أو انتمائهم الثقافي بين الشرق والغرب - على افتراض أن العقل المصري احتفظ طوال القرون بعناصر معينة في ثقافته - وهي مصادرة تحتاج إلى إثبات -، وقرر لأجل هذا أن "العقل المصري منذ

DINIKA, Volume I, Number 3, September - December 2016 
عصوره الأولى عقل إن تأثر بشيء فإنما يتأثر بالبحر الأبيض المتوسط، وإن تبادل المنافع على الما

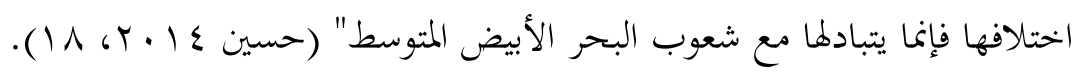

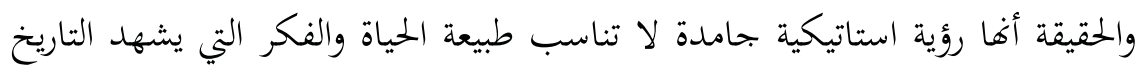

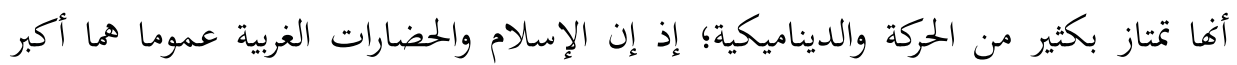

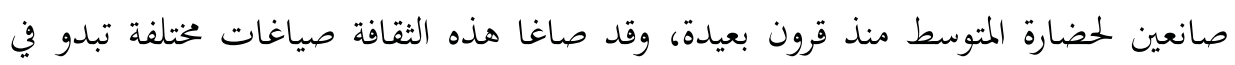

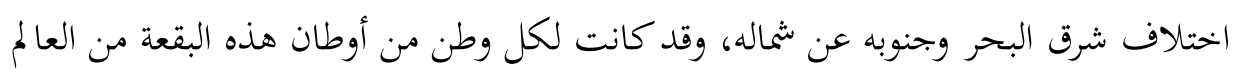

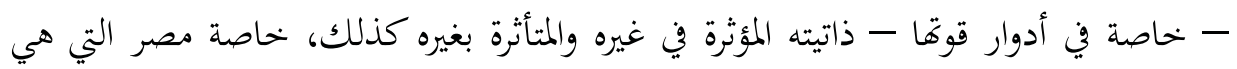

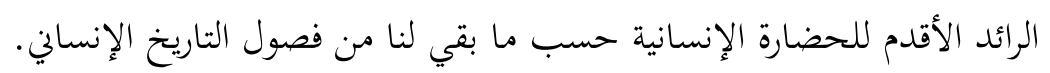

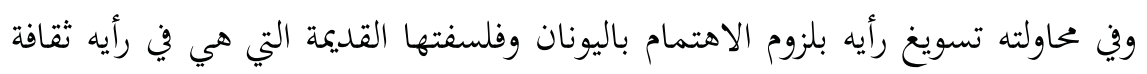

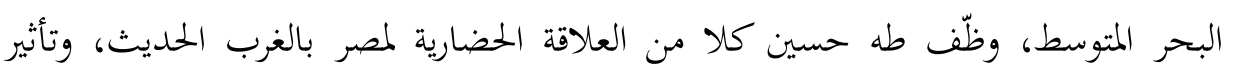

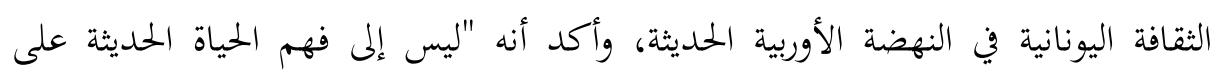

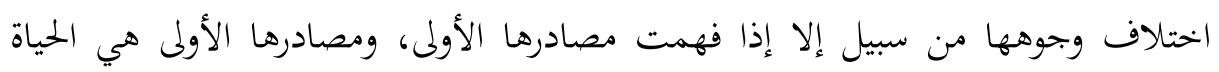

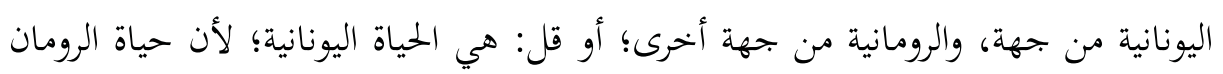

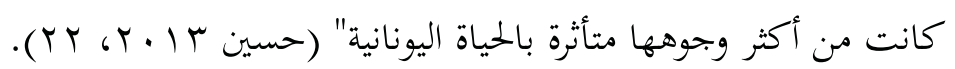

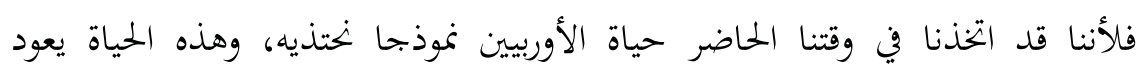

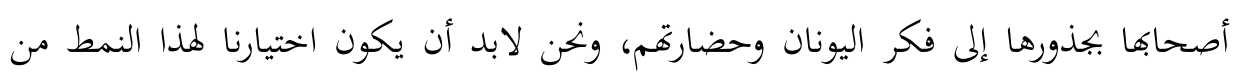

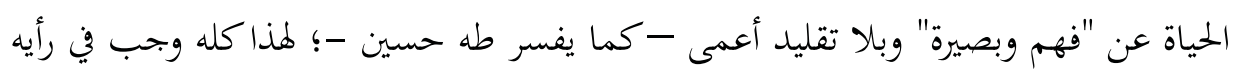

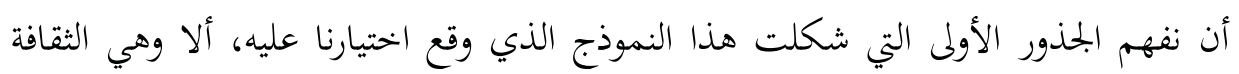
اليونانية القديمة، والتي تمثلها الفلسفة ورجالاتها المبرزون.

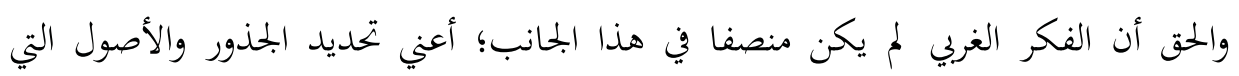

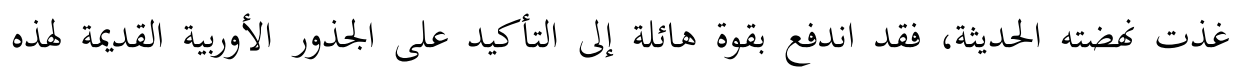


النهضة، فأرجعها كلها تقريبا إلى ما ورثه عن تراث اليونان والرومان، في حين بدا التأثير

$$
\text { الإسلامي في هذا الجانب ضئيلا، بل معدوما أحيانا. }
$$

لقد كان غالب التيار التأصيلي الساري في الفكر الغربي يؤكد على الجذور الداخلية

التاريخية والحالية لنهضته، في حين بدا المعترفون بحقيقة الدور الإسلامي في النهضة الحلديثة تيارا

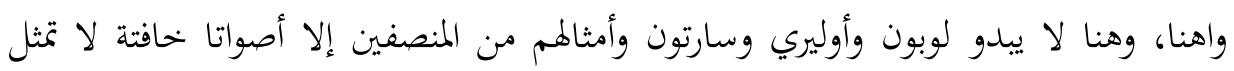
شيئا إزاء الضجيج العالي للرأي الآخر.

ويبدو لي أن هذا هو الذي صنع موقف طه حسين من هذه القضية في هذه المرحلة

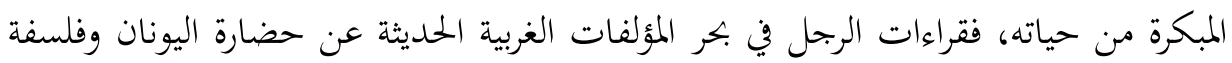
اليونان وإبحازاقم في الفن والسياسة والعلم، وقبل ذلك تتلمذه على أعلام الفكر الغربي في الفي القاهرة وباريس ترك آثاره التي لا تُنكر على فكره وعقله في هذه القضية وجملة قضايا أخرى.

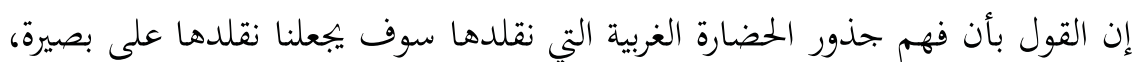
لا يبدو منطقيا؛ لأنه ليس هناك تقليد على بصيرة وتقليد على غير بصيرة، بل التقليد في أي

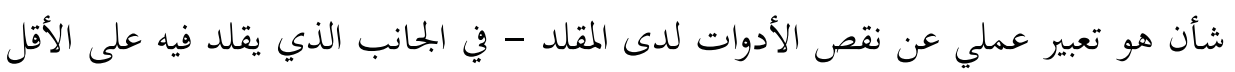
- - وإذا كان هذا التقليد في نظام الحياة والتعليم والتثقيف والعيش فهو ذوبان وتضحية بالهوية الخاصة.

\section{تأثير أرسطو}

وإذا كان طه حسين يذهب هذا المذهب في تقدير الدور الثقافي لليونان عموما، فإنه

قد عبر عن تقديره الخاص لأرسطوطاليس؛ تلك الشخصية الفلسفية المهمة التي استقصت "في المنطق - كما يقول - قوانين العقل الإنساني في البحث والتفكير على اختلاف درجاتما

DINIKA, Volume I, Number 3, September - December 2016 
وأطوارهما؛ وهذه القوانين ثابتة لا تتغير، ملائمة للإنسان من حيث هو إنسان، لا من حيث

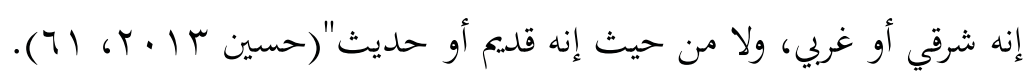

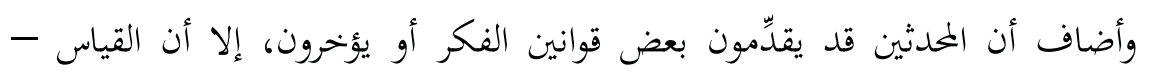

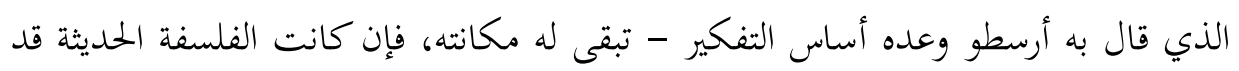

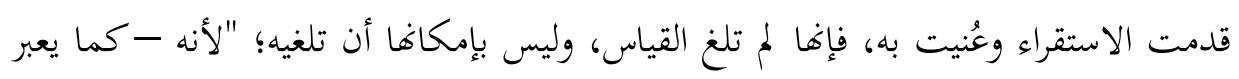

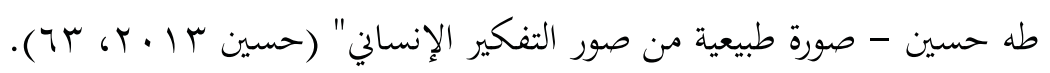

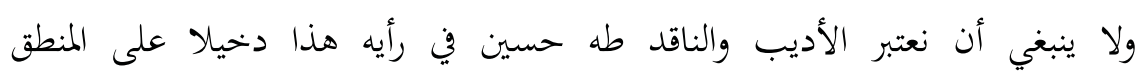

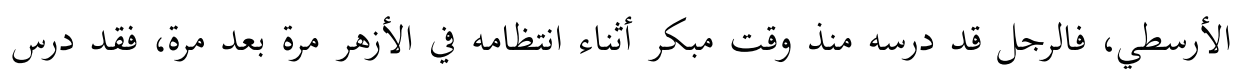

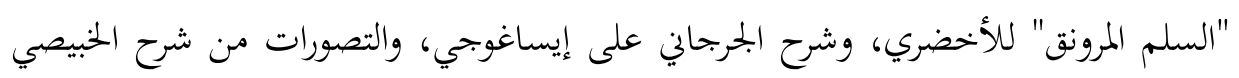

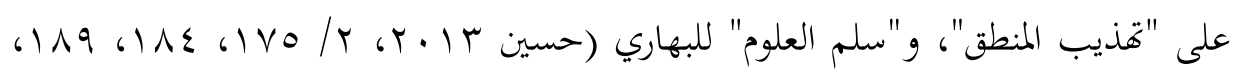

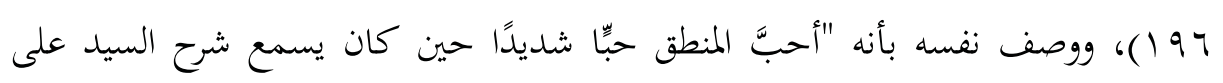

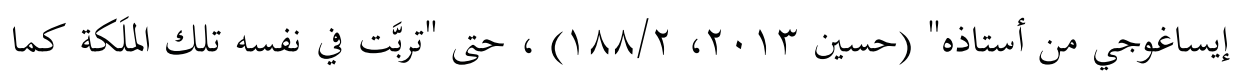

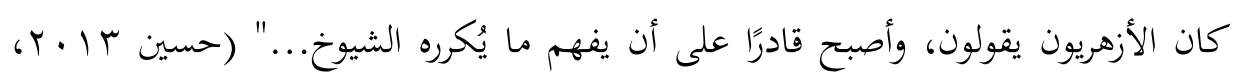

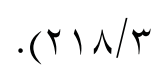

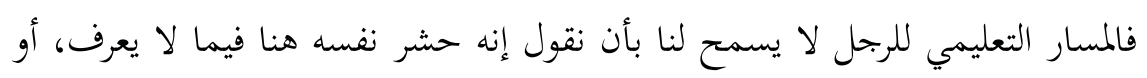

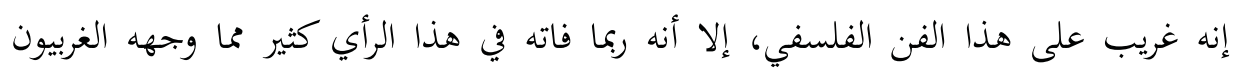

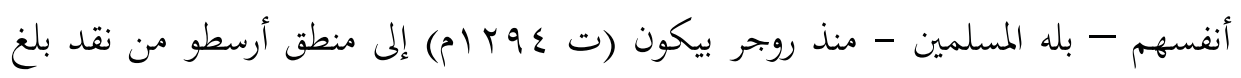

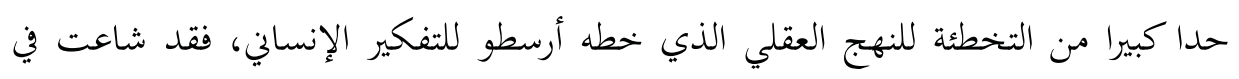

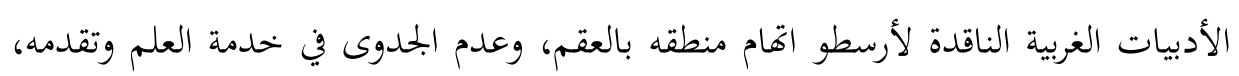

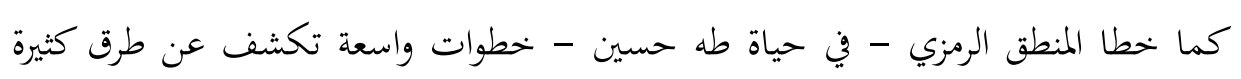

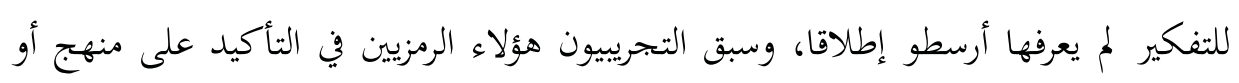


مناهج أخرى مختلفة للبحث في العلوم لم يعرف منها أرسطو إلا النزر اليسير، وأهم ما فيها هنا هو أهما تصف القياس الأرسطي بأنه قائم على أصل غير ثابت، فهو لا قيمة له ولا لنتائجه ما لم نقمه على استقراء علمي دقيق.

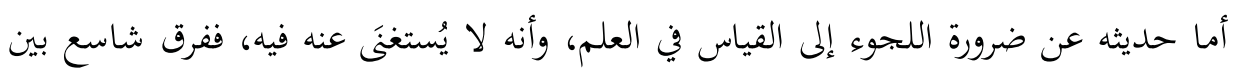
القياس القائم على أصول واضحة ومعلومات علمية صحيحة خضعت للملاحظة والاختبار الدقيق كما هو شأن المنهج العلمي، وبين قياس واهٍ يوظفه صاحبه في استنباط ما لا نفع فيه للعلم ولا الحياة، وما لا يقين في صحته من المعلومات المرسلة. مهما يكن، فإن طه حسين إن كان يسجل هذا عن مكانة المنطق الأرسطي خاصة، ونها،

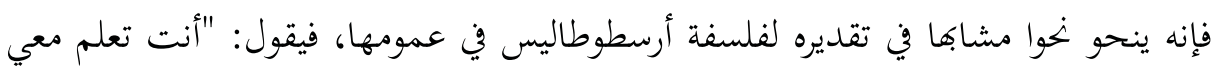
أن فلسفة أرسطاطاليس سيطرت منذ ظهورها على العقل الإنساني القديم، وأها هي التي كان

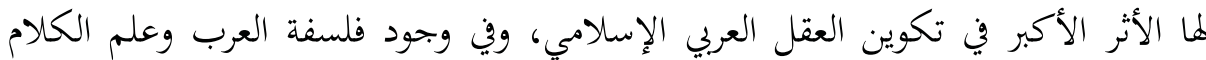

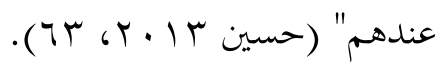

وأكد هذا الرأي في مقدمة ترجمته لكتاب "نظام الأثينيين" - التي تعد واحدة من خدمات طه حسين التي قدمها للتراث اليوناني - حين قال عن مؤلفه أرسطو: "فلسفته قد

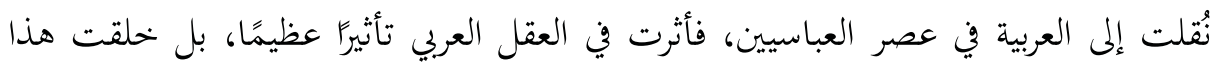
العقل خلقًا جديدًا، وأنجبت من الفلاسفة أمثال الفارابي وابن سينا وابن رشد وغيرهم من تهري الفلاسفة الذين يزدان بهم تاريخ المسلمين" (أرسطوطاليس، ترجمة: طه حسين ع ا • ب، . ).

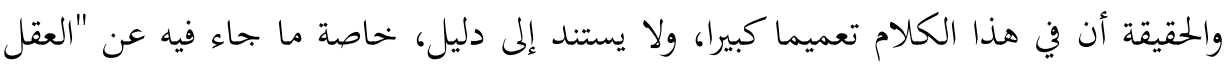
العربي" و "خلقه" خلقا جديدا؛ إذ ليس دقيقا أن نثبت أي دور للفكر اليوناني في تكوين العقل الإسلامي بدون مراعاة حقيقة أن ترجمة الفكر اليوناني إلى العربية لم تستقر إلا بعد هاية

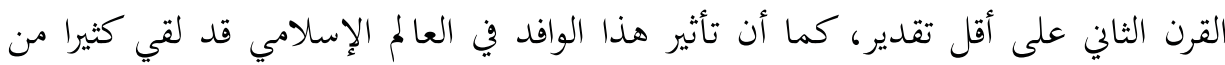

DINIKA, Volume I, Number 3, September - December 2016 
المقاومة الشرسة، وفي النهاية فقد استقلاله بأن صار مبحثا في بعض العلوم الإسلامية، أو

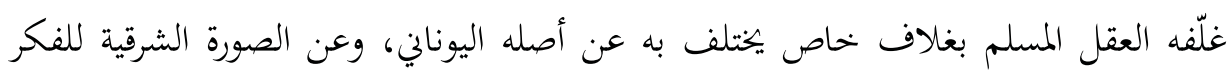

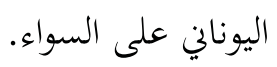

ومع هذا، فلا شك أن الفكر اليوناني كان له تأثيره المتصاعد في الحياة العلمية والفكرية

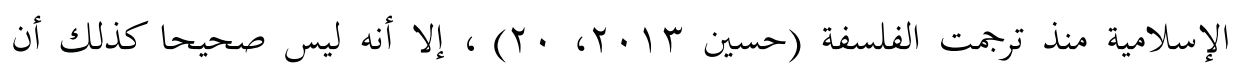

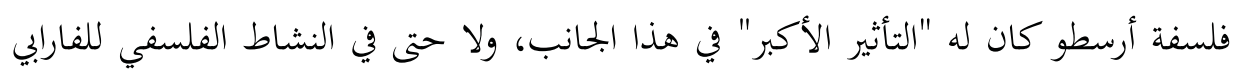

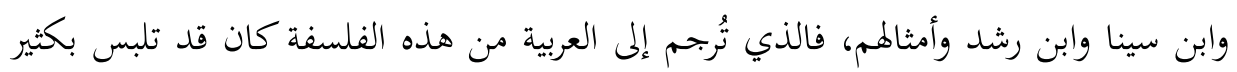

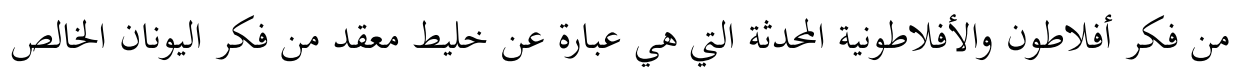

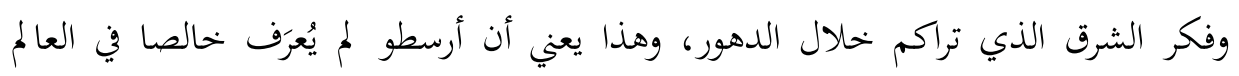
الإسلامي إلا في أحوال قليلة كما استقر عند الدارسين.

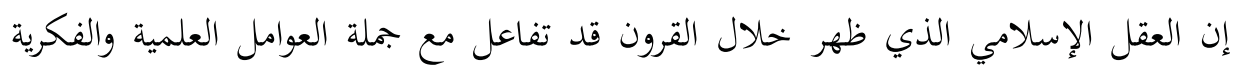

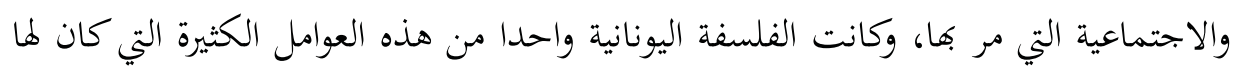
تأثيرها المهم، إلا أن التضخيم من هذا التأثير يجافي روح العلم، ويفتقر إلى الأدلة المقنعة.

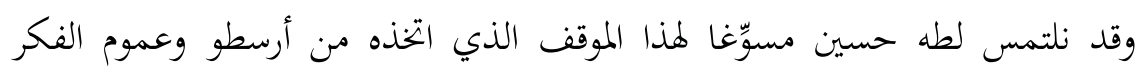

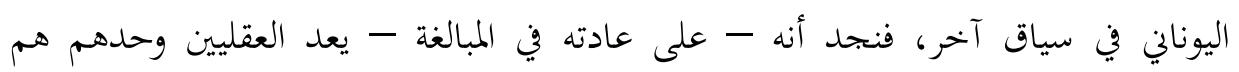

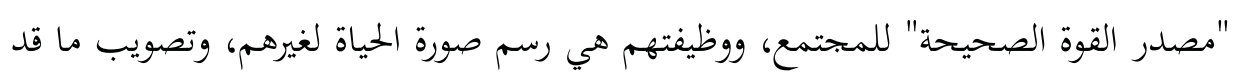

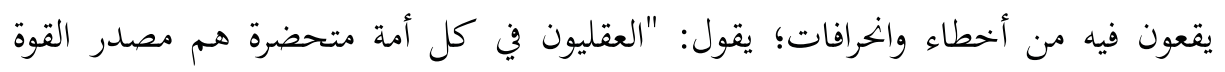

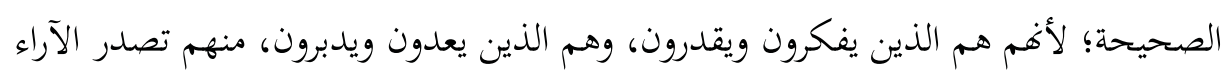

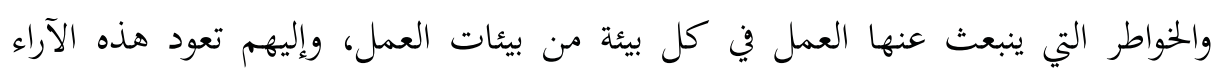

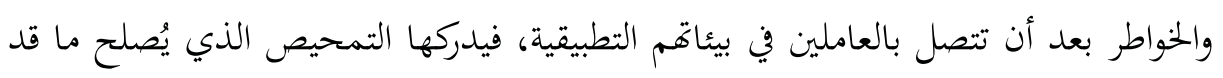

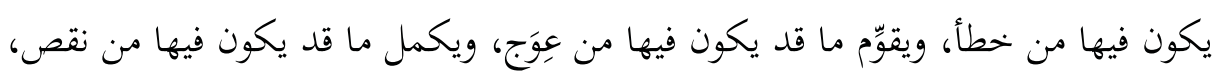


ويحذف ما قد يكون فيها من زيادة، ويهدئ ما قد يكون فيها من غلو وإسراف" (حسين

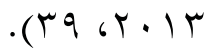

وقد استعمل طه حسين لفظ "العقليين" هنا مقابلا للفظ "العاملين"، وعنى بالأول أساتذة الجامعة والمدارس الفنية الخاصة والعاملين في معامل التجربة والإحصاء (حسين r ا • ץ، • ع)، وعند النظر بند أن هؤلاء فريقان اثنان: النظريون الذين يقدمون للمجتمع الأفكار والآراء الخالصة حول ما هو قائم وما ينبغي أن يكون في مختلف المحالات التي تقوم عليها حياة الناس، والتجريبيون الذين يقدمون للمصانع قوانين العلم مثبتة وقابلة للترجمة إلى آلة أو جهاز تقوم بإنتاجه ماكينات المصانع وأيدي الصناع. ومن هنا ليس غريبا أن ينحو طه حسين في تحديده للقوى الضاربة في المحتمع الإسلامي نحوا يركز فيه على طائفة العقلانيين المسلمين المتأثرين بالتراث اليوناني، ويقيس بهم قوة الحياة وضعفها، ولا يتسع نظره ليشمل قطاعات أخرى واسعة من العلماء اشتغلوا بعلوم اللغة والدين، وكأن العقل خاص بالفلاسفة ومن لاصقهم من الأطباء والمهندسين والفلكيين والكيميائيين وحدهم. ولهم.

إلا أنه لا يفوت المدقق أن حضارة الإسلام برمتها كانت حضارة عقل، وقد بحث

الدكتور زكي بنجيب محمود - أحد ألمع الدارسين العرب للفلسفة والفكر في القرن العشرين إندان عن أهم ما كان يميز العرب والمسلمين في مراحل تفوقهم الحضاري، وخلص إلى أها النظرة

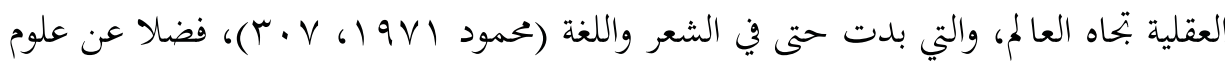
العقيدة والتفسير والفقه وأصوله، وغير ذلك من العلوم

DINIKA, Volume I, Number 3, September - December 2016 


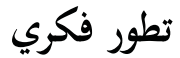

ولعل الدكتور طه نفسه قد شعر بأن مواقفه هذه لم تكن إلا وليدة الحماسة للثقافة

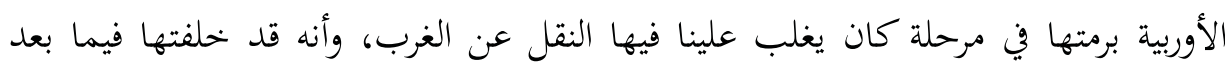

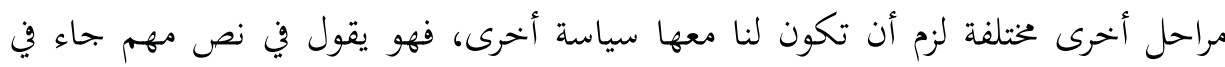

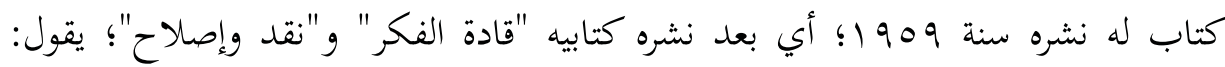

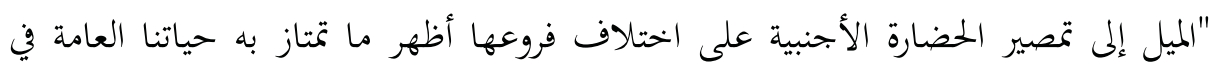

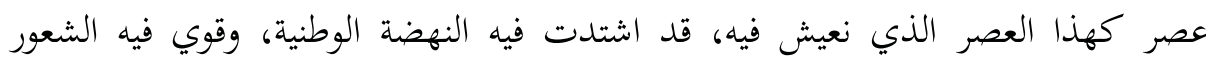

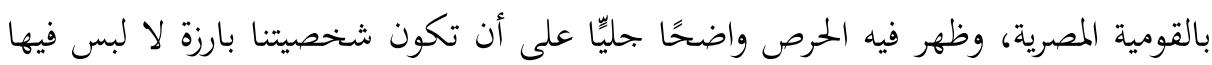

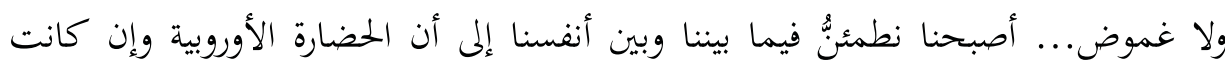
ضرورة من ضرورات حياتنا الفردية والاجتماعية؛ فإن لنا مقوّمات خاصة ليست حاجنات الفتنا إليها

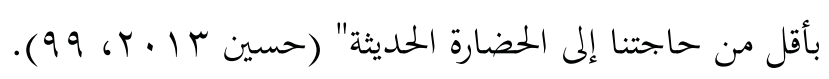

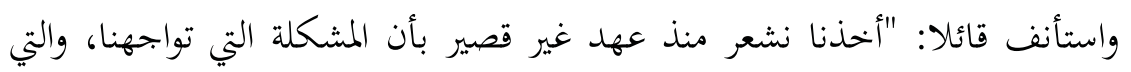

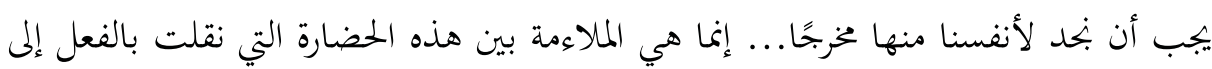

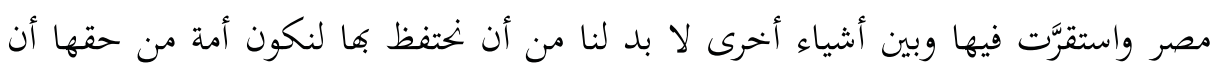

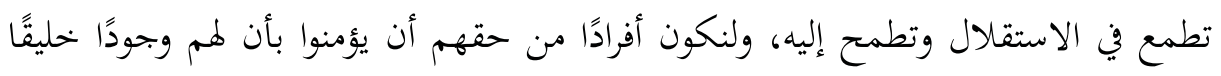

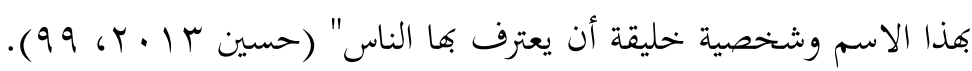

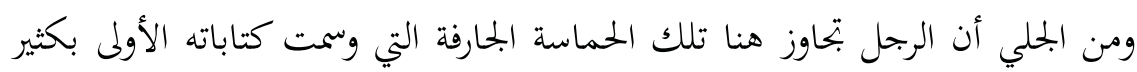

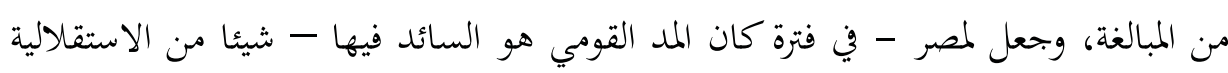
تجاه قادة الحضارة القائمة.

ولا ينفي هذا أن طه حسين بقي معجبا بالإنحاز الحضاري الأوربي الحديث والإنحاز

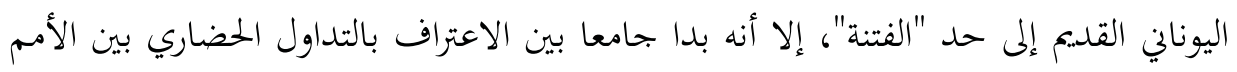




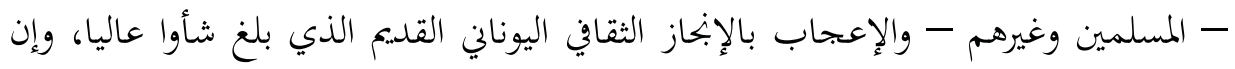

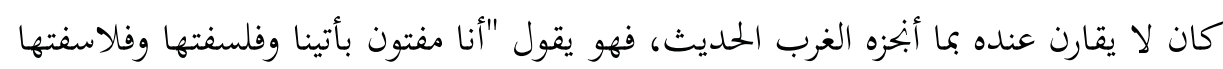

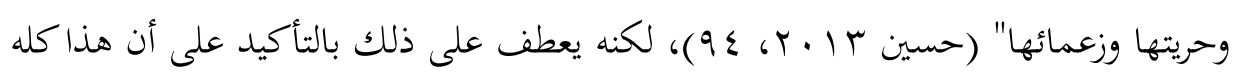
ليس بشيء إذا قورن بباريس وفلسفتها وحريتها الآن.

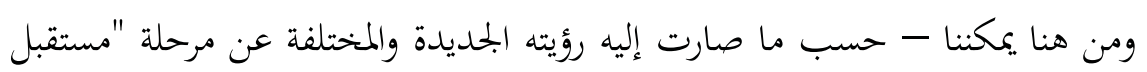
الثقافة في مصر" - يككنا فرز العناصر الإيجابية للحضارة الغربية من عناصرها السلبية،

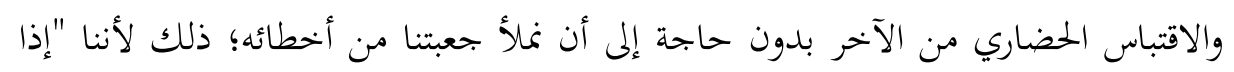

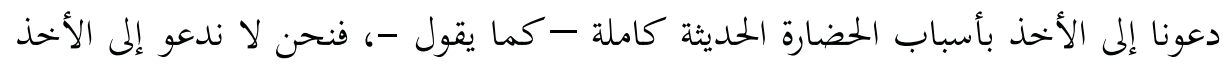

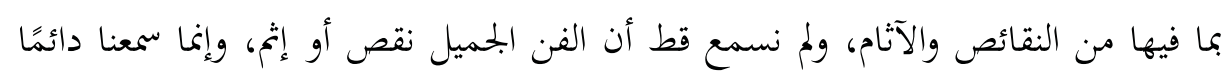

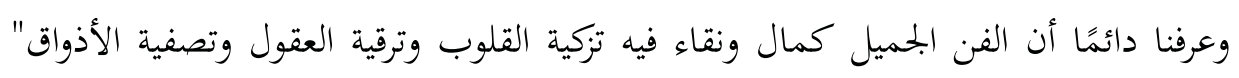

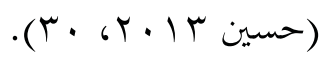

والأخذ عن حضارة اليونان أو أي حضارة أخرى متفوقة شيء مسوَّغ تماما، وإذا كنا

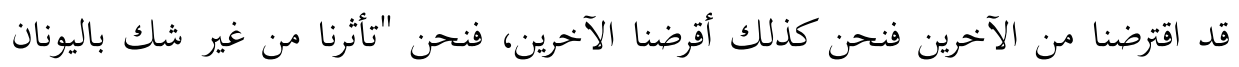

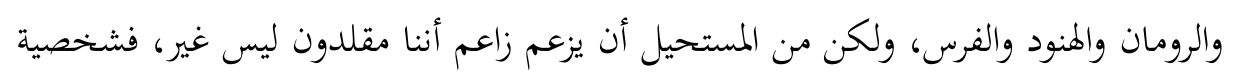

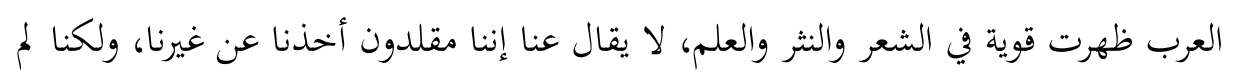

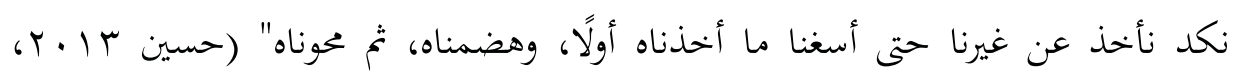
.$(19$

ويكفي في نظره "أن نلاحظ أن النهضة الأولى التي ظهرت في القرن الثاني عشر في

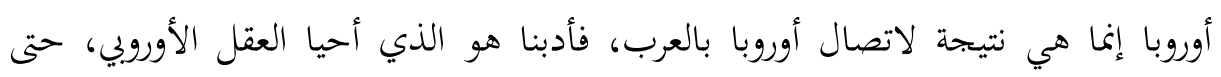

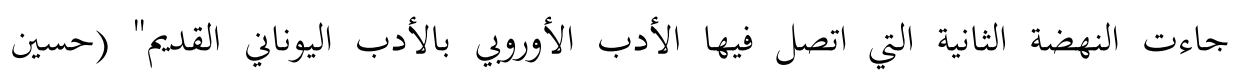

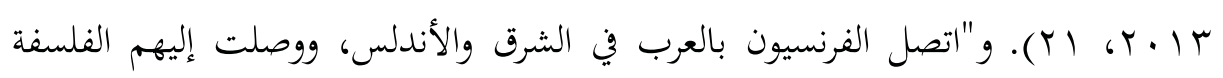

DINIKA, Volume I, Number 3, September - December 2016 
الإسلامية، فأنشأ وصولها إليهم حركة فكرية جعلت لهم فلسفة يدرسونا ويدافعون عنها"

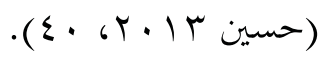

وليس من العسير أن تكتشف أن مزاج طه حسين الحاد كان له دوره الحاسم في كثير

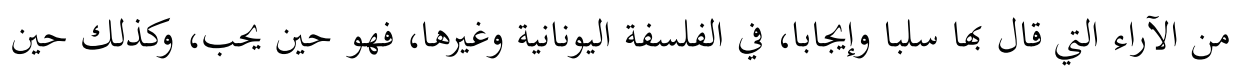

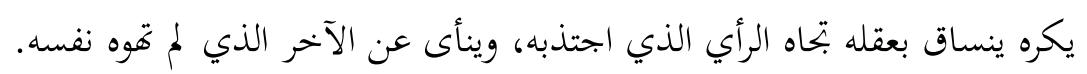

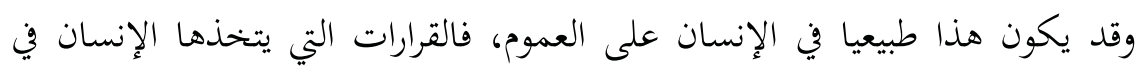

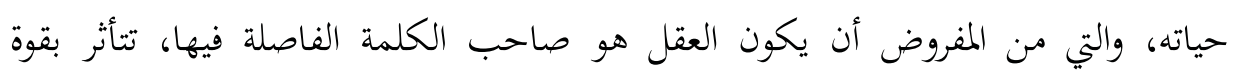

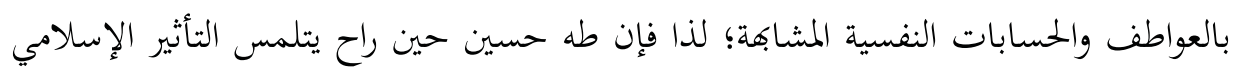

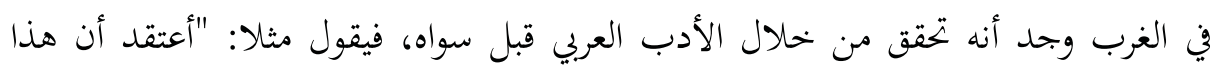

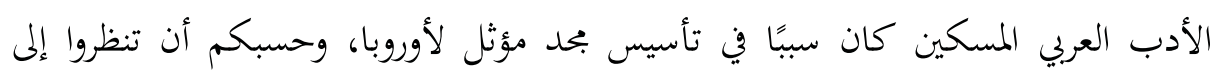

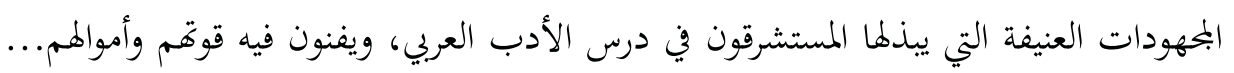

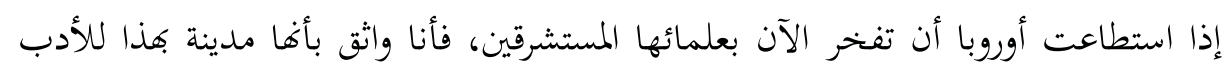

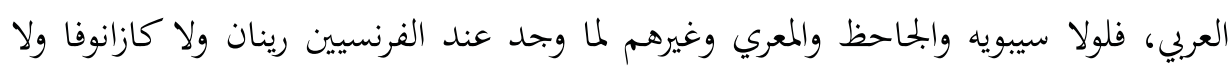

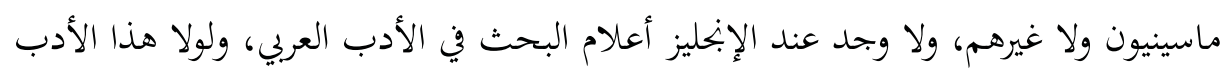

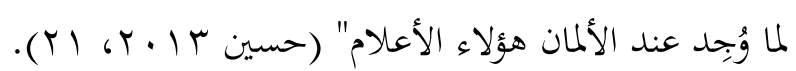

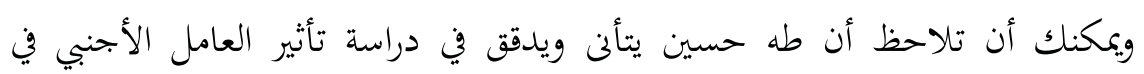

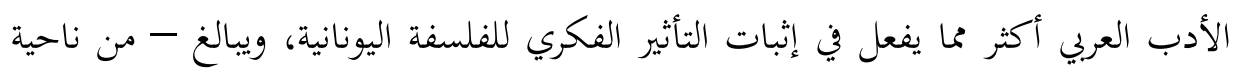

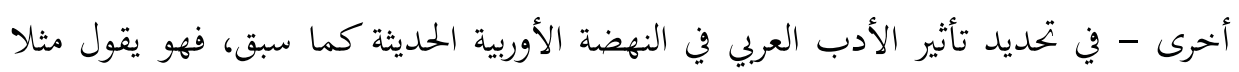

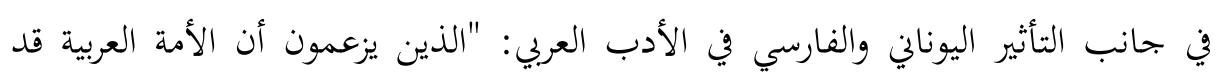

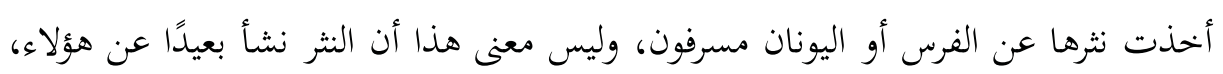

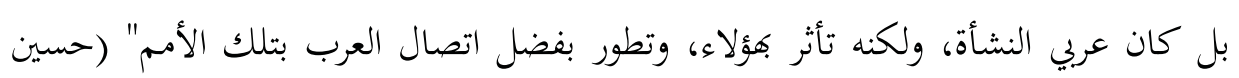




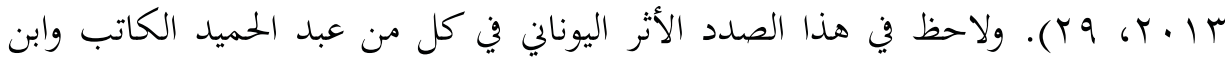

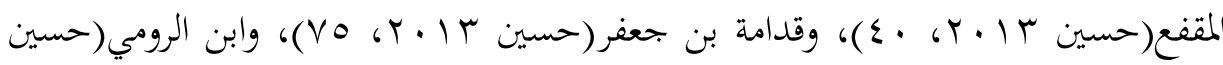
$\cdot(1 T), t \cdot 14$

وهذا هو الرأي الذي يشهد له تاريخ العلم في أكثر الفنون والعلوم الإسلامية، أو التي مارسها المسلمون؛ إذ نشأت نشوءا إسلاميا خالصا، وتطور بعضها تطورا أبلغها درجة الكمال أو قريبا منها، تم دخلت عليها عوامل تطوير مختلفة، كان العامل الأجنبي واحدا منها، وقد تفاوت تأثير هذا العامل من علم إلى آخر، حسب قرب العلوم الوافدة من كل علم منها، وحسب اهتمام أصحاب كل علم بالعلوم الأجنبية وإهمالهم لها. قل ذلك في الفقه وأصول الفقه وعلم الكلام والتفسير والتصوف وعلوم اللغة وغيرها. ولهذا بند طه حسين في كتابه "من بعيد" الذي نشره في صورة مقالات بين عامي

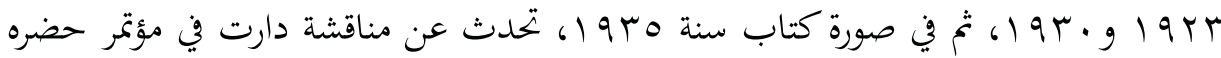
في بلجيكا سنة r 19 حول ورقة عرضها لويس ماسينيون ناقش فيها أصالة التصوف الإسلامي، وذهب إلى أن "التصوف - كما يعبر الدكتور طه حسين - عربي خالص، أو

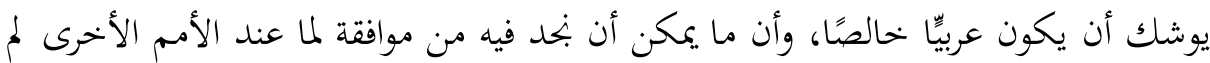
يؤخذ عن هذه الأمم، وإنما هي المصادفة وتوارد الخواطر ووحدة النظام العقلي في التفكير مهما

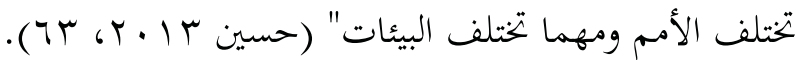
وقد ناقش ماسينيونَ في رأيه هذا جماعةٌ من الحاضرين، منهم طه حسين نفسه الذي

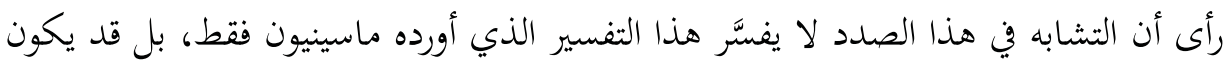
من تأثير الأمم بعضها في بعض، وضرب لذلك مثلا بقوله: "إذا ثبت أن اليونان مثلًا كانوا يرون هذا الرأي بعينه، وكان فلاسفتهم يشرحونه ويفسرونه ويدرسونه في المدارس المختلفة، وأن بـان

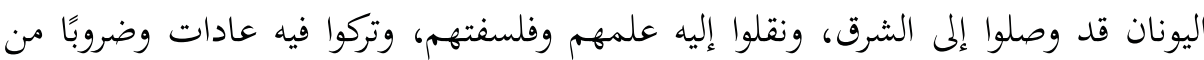

DINIKA, Volume I, Number 3, September - December 2016 
التفكير ليس إلى إنكارها من سبيل، وإذا ثبت أن هذه الآراء أو هذا الرأي لا يلائم ما نعرف

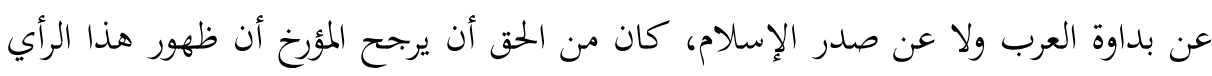

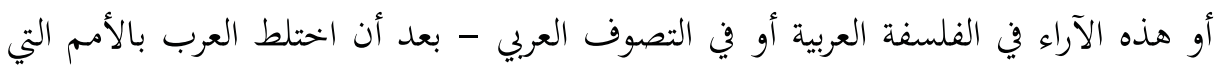

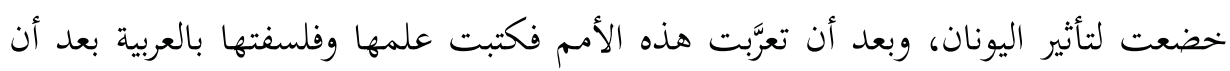

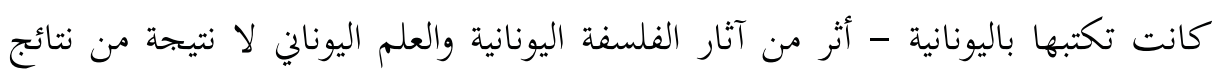

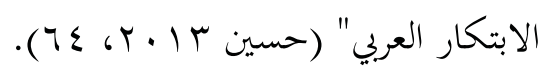

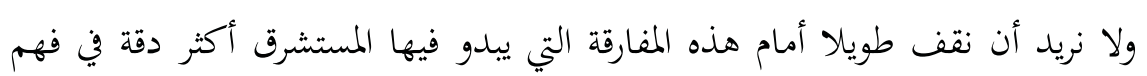

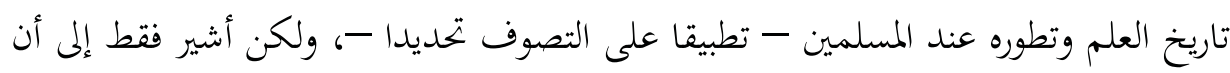

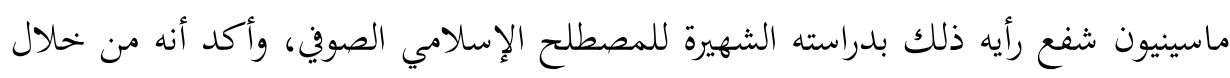

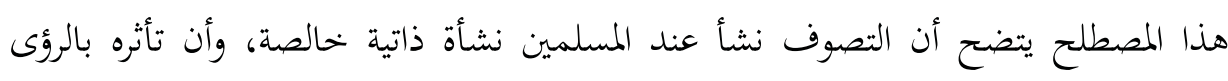

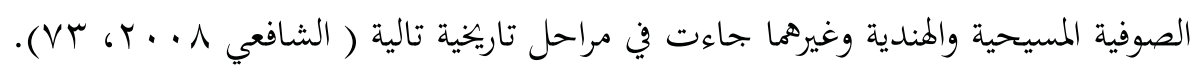

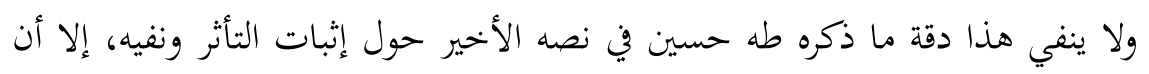

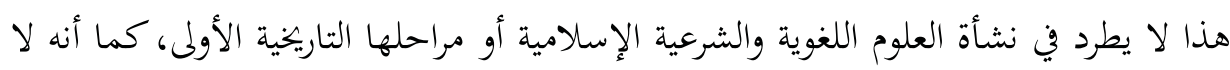

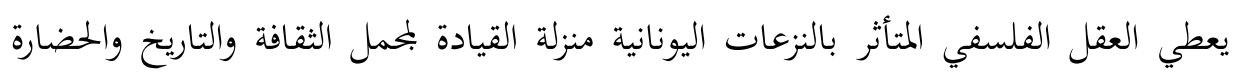

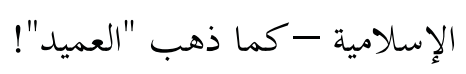




\section{المبحث الثاني: موقف عباس العقاد من الفكر اليوناني}

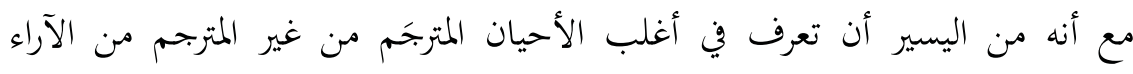

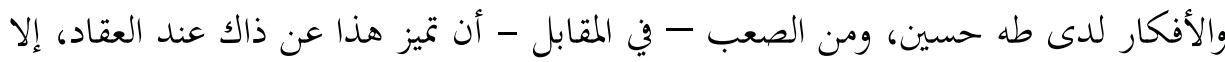

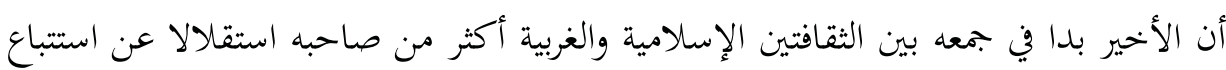

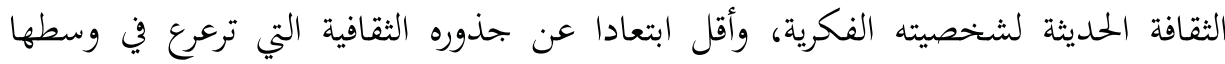

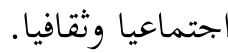

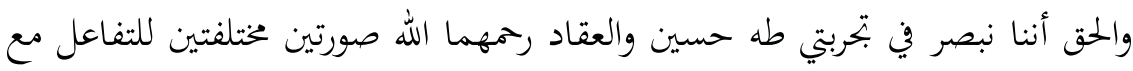

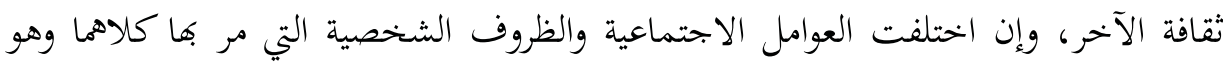

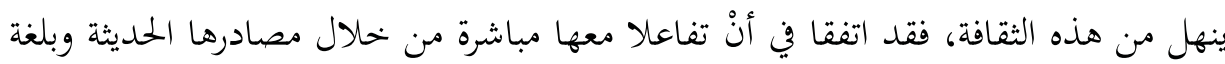
أوربية ذائعة، وهي الإنخليزية في حق العقاد، والفرنسية في حق طه حس حسين. ولعلنا نحاول أن نرصد في سطور هذا المبحث بتحليات هذه الاختلافات والاتفاقات

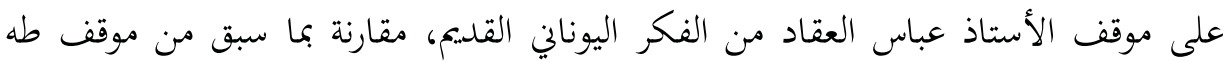
حسين منه.

ومع أن العقاد يصف الفلسفة اليونانية في بعض كلامه بأها مغالطات وتخمينات

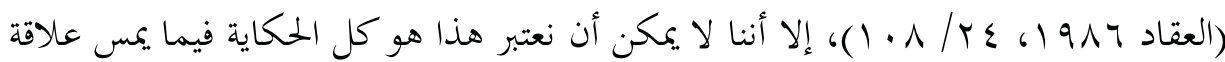

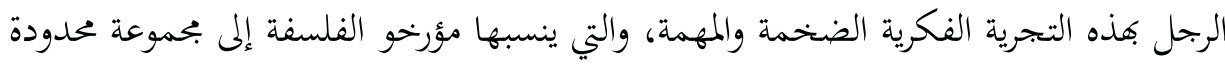

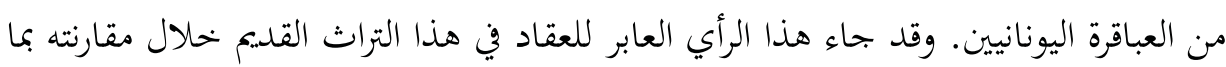
أتاحه العصر من تقدم علمي وثقافي أكثر جدوى لعائر للإنسانية.

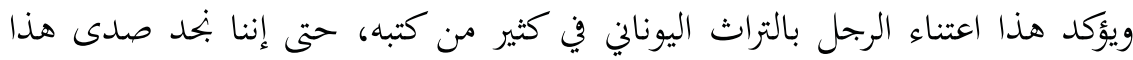

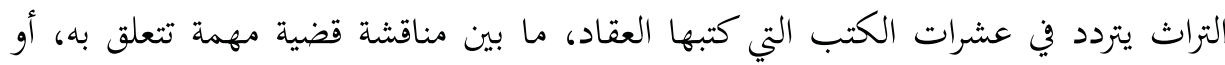

DINIKA, Volume I, Number 3, September - December 2016 
إيراد موقف فكري لأحد أعلامه في سياق يستدعيه، أو اقتباس قولة لأرسطو أو سقراط أو

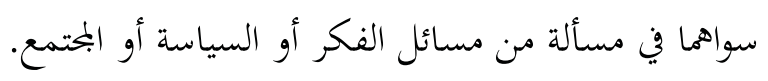

\section{نشأة الفلسفة في اليونان}

ولعل أهم قضية شغلت فكر العقاد من قضايا الفلسفة الإغريقية، هي السبب الذي

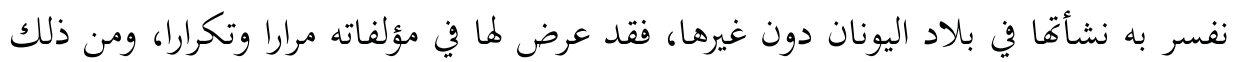

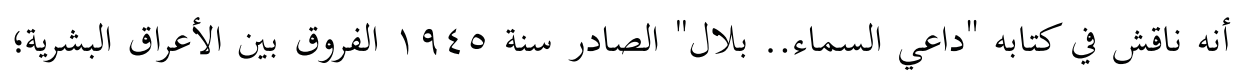

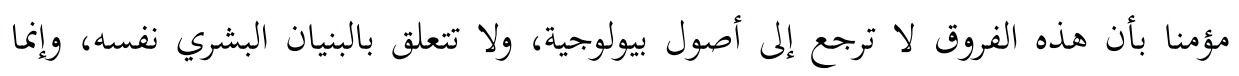

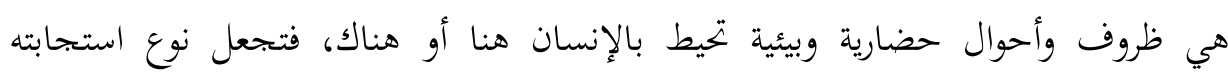

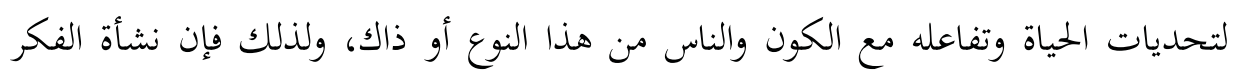

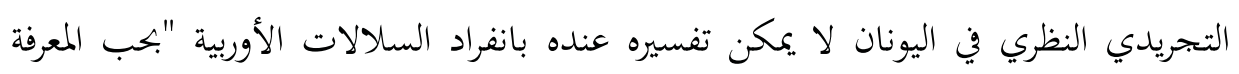

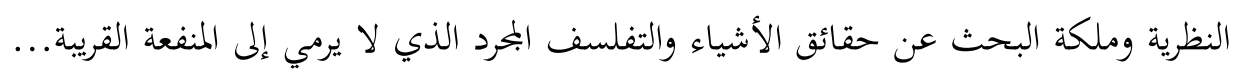

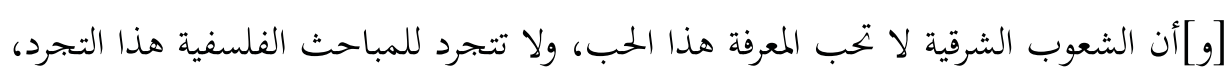

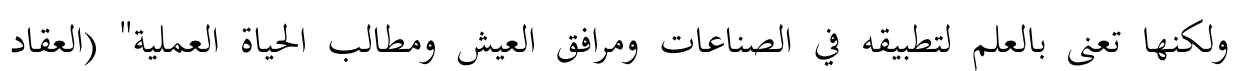

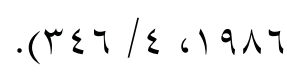

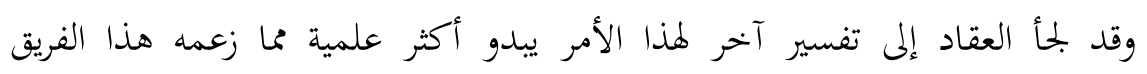

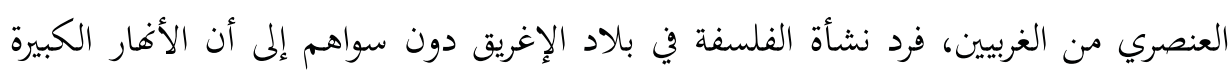

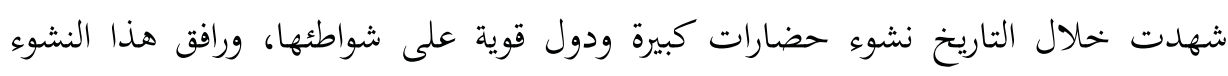

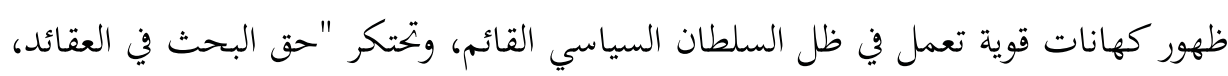

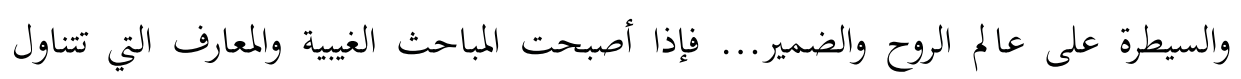

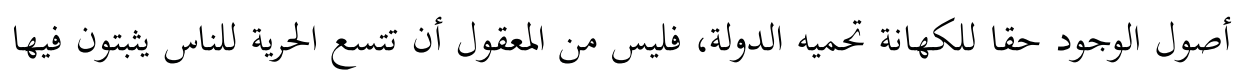




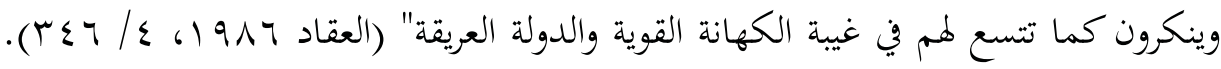
ومن هنا ظهرت الفلسفة - في رأيه - في بلاد اليونان، ولم تظهر في أودية الأهار الكبرى، تين، مثل: النيل ودجلة والفرات وسواها. ويستدل العقاد لهذا بحال أوربا بعد أن توطدت بها سلطة الكنيسة، وأنما صنعت حينها

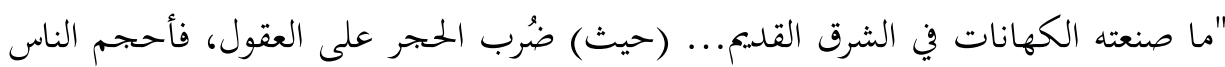

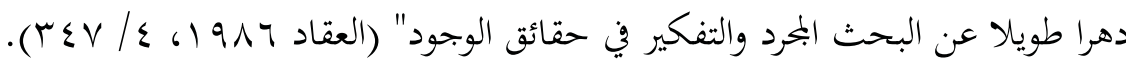

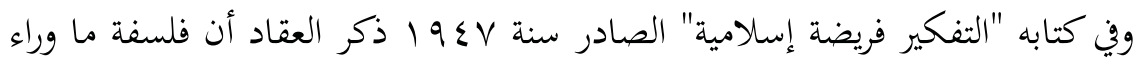
الطبيعة لم تظهر في البادد الكبرى لأها "لم تكن بيئات صالحة لنشأة هذه الفلسفة ونبوغ فلاسفتها"، وأن الأمر غير مرتبط بمستوى التحضر . ثم عرج على موقف الباحثين الأوربيين في

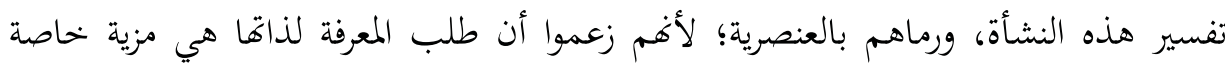
للعقل الأوربي دون غيره، وأها السبب في ظهور الفلسفة في أحد أقطار هذه القارة وحدها. واحتج عليهم بأن أوربا نفسها حجرت على الفلسفة في بعض الأوقات؛ وذلك لأن قوة

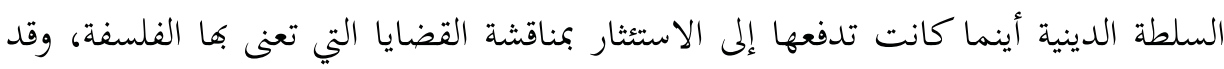
سلكت هذه السلطة المسلك نفسه في الشرق أحيانا وفي الغرب أحيانا أخرى، وفي المقابل حيثما خفتَ صوت الكهانات الدينية ارتفع صوت الفلسفة، وهذا ما ينطبق على التجربة اليونانية القديمة في الفلسفة، وعلى استيعاب العالم الإسلامي للفلسفة كذلك (العقاد بـ19 1) . (rTO/O

وفي كتابه "إبليس" الصادر سنة 1900 ذهب العقاد إلى الرأي نفسه في تفسير نشأة

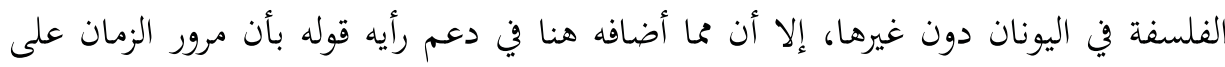

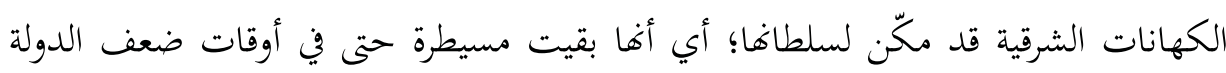
بسبب السلطة التي حققتها لها تراكمات العصور، كما أن يونان الفلسفة التي لم تكن فيها

DINIKA, Volume I, Number 3, September - December 2016 
كهانة راسخة قتلت سقراط، وفر منها خوفا على حياته فيثاغوراس وأرسطو وغيرهم، فما بالنا

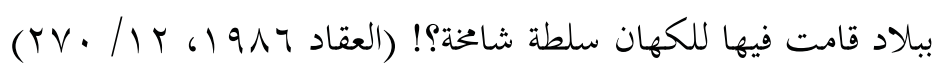
ومع أن رأي العقاد هنا في تفسير نشأة الفلسفة في موطنها الأول له وجاهته، إلا أنه قد يصلح للنفي دون الإثبات؛ أعني أنه قد يفسر لنا عدم ظهور الفلسفة في الشرق، إلا أنه لاه

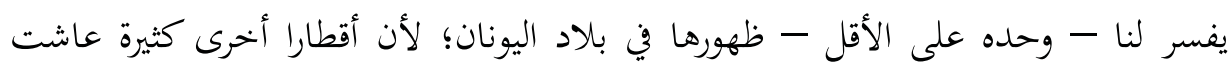

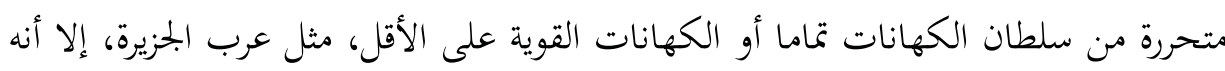
لم يُنتَّل لنا أفم اشتغلوا بالفلسفة، ولا معالجة موضوع الوجود علاجا يغلب عليه التجريد والنظر الكلي للأمور.

وقد فسر الفيلسوف الإنحليزي الشهير برترند رسل عدم ظهور الفلسفة في الحضارات الشرقية

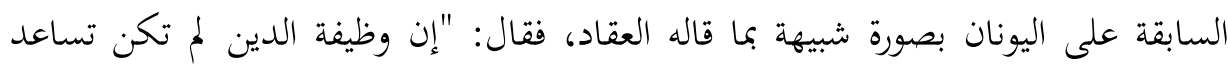

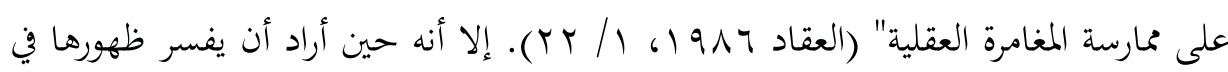

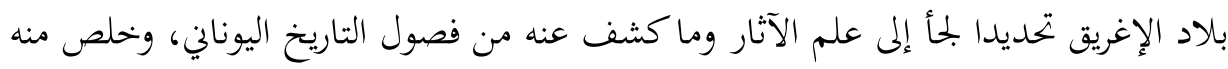

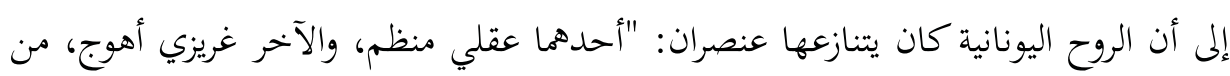

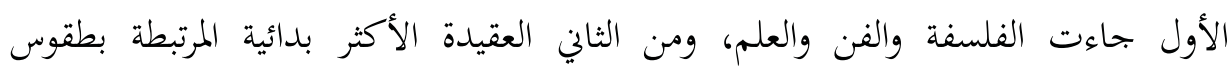

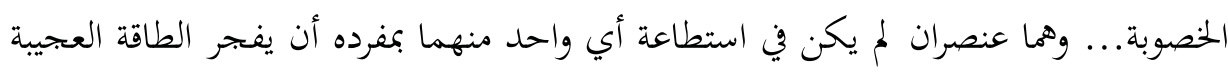
للحضارة اليونانية، ففي الشرق كان العنصر الصوفي يسيطر بلا منازع، ولكن ما أنقذ اليونانيين من الوقوع في براثن هذا العنصر وحده هو ظهور المدارس العلمية في أيونية. ومع ذلك ينبغي بلني

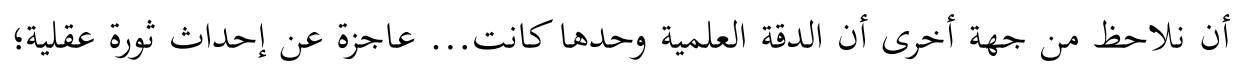

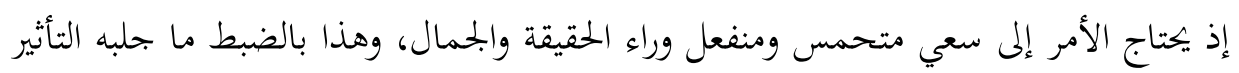

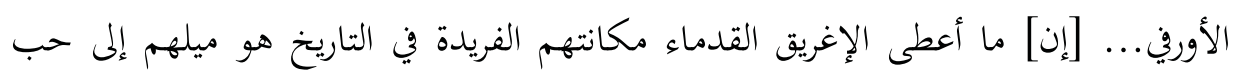


الاستطلاع الذي لا يرتوي، والذي يدفع المرء إلى القيام ببحث مشبوب بالانفعال يكون مع

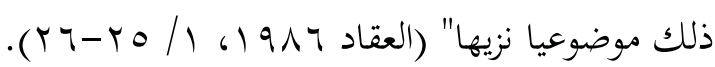

ومع أهمية رأي رسل وتحليله هنا كذلك، إلا أن هذه الظروف لم تكن خحاصة باليونان وحدهم طوال التاريخ، ومن هنا تبدو المسألة أكثر تركيبا وفي حاجة إلى مزيد من الاستقراء والفحص، وإن كان العقاد يلفت نظرنا إلى نقطة مهمة قد تعيننا في هذا السبيل، فهو يقول

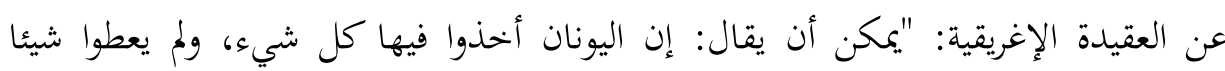

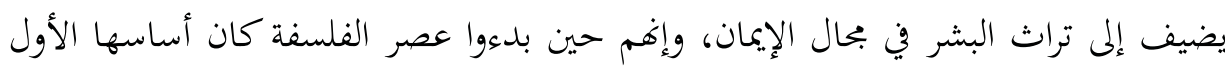

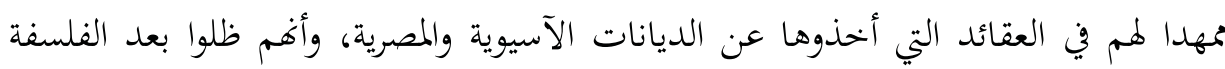

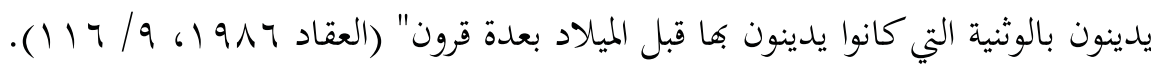
وهذا يعني أن الأفكار الدينية التي عاشت عليها اليونان، وكانت سببا في طرح كثير من قضايا الميتافيزيقا هي أفكار مستوردة بكاملها، وأن الفلسفة جاءت في كثير من الأحيان لتسويغها أكثر مما جاءت لتعديلها أو تصحيحها، وما اعتراض سقراط على النظام الديني

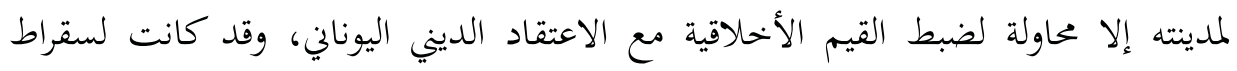
وتلاميذه علاقات إيجابية معروفة بمعبد دلفي صاحب السلطة الدينية في أثينا. وكذلك كانت الأفكار الاعتقادية في فلسفة كل من أفلاطون وأرسطو منطلقة من تراث

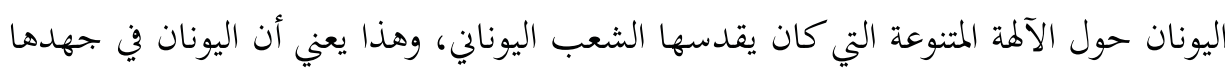

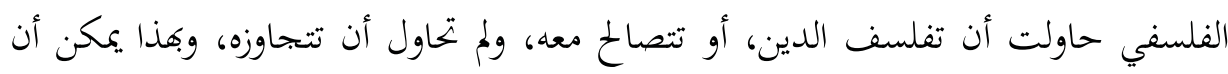

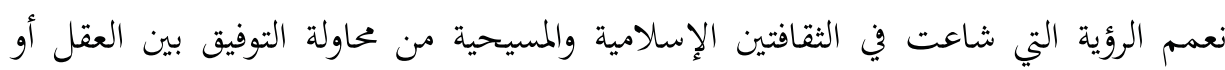

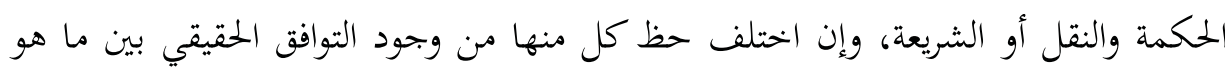
عقل وما هو نقل. - مقان.

DINIKA, Volume I, Number 3, September - December 2016 
وقد يفيدنا هذا في التأكيد على أن مؤثرات كثيرة متنوعة؛ معروفة وبحهولة، داخلية وخارجية، سياسية واجتماعية واقتصادية، قد اجتمعت لليونان في مرحلة ما من تاريخها حتى أنتجت الفلسفة والأدب المنسوب إليها في رقعة جغرافية أوسع من اليونان ومن خلال شخصيات تنتمي إلى قوميات لا تنحصر في الإغريق وحدهم. ولعل من الملائم أن نورد هنا جانبا من مفاضلة بين اليونان وبعض الأمم أوردها العقاد

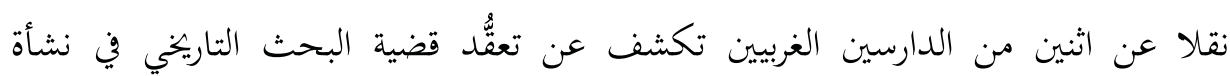
الفلسفة، حتى إنه يترجح من خلال هذه المفاضلة أن هذه النشأة كانت أشبه بالعمل الدولي

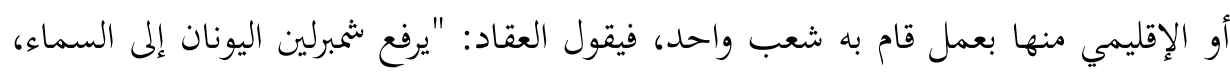

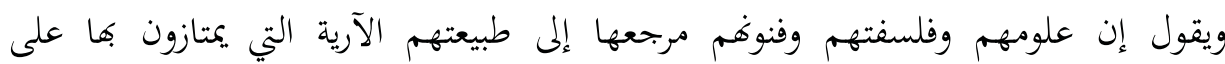

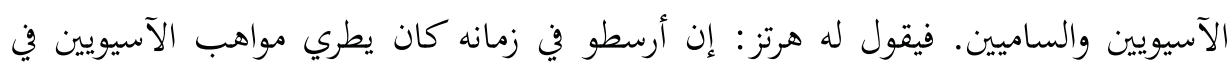
الفنون، ويحكم على أمم الشمال بالعقم الذي لا علاج له في المعارف الفنية والسياسية لعلة الجو التي لا تبديل لها على تعاقب الأزمان. ويقول هرتز أيضًا: إن ثيوسيديد المؤرخ اليوناني

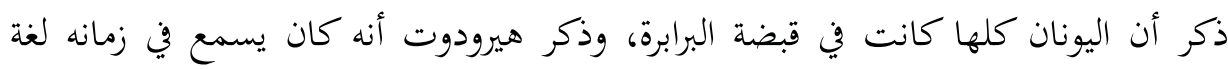

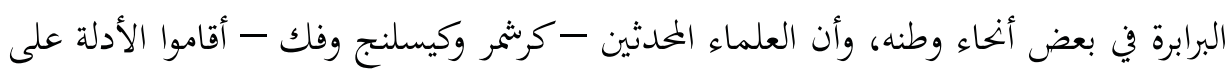

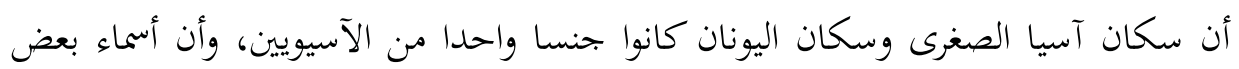
المواقع اليونانية لا ترد إلى مصادر من هذه اللغة؛ لأهما مشتقة من اللغة القديمة كما اشتقت

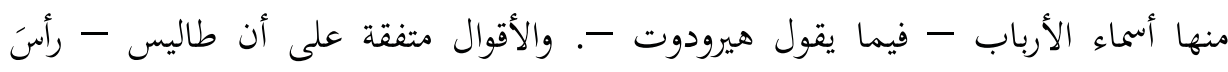

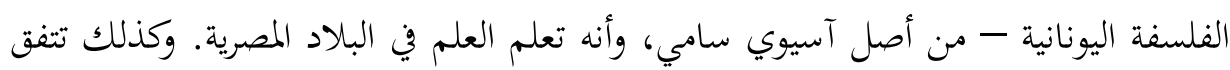

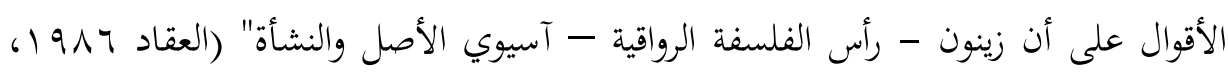
. (TVV/ T T 
وفي كتابه عن الشاعر ابن الرومي الذي سجلت كتب السير أنه كان من أرومة يونانية

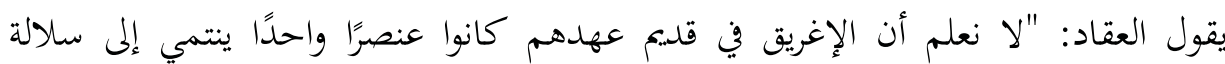
واحدة؛ لأن امتزاج الأنساب بينهم وبين الآسيويين ثابت لا شك فيه، واقتباسهم من عقائد

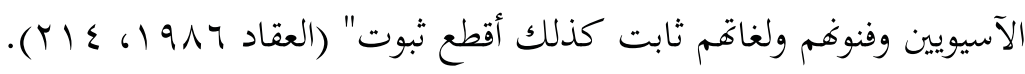

\section{الدراسات الغربية حول اليونانيين}

إذا كان العقاد قد عالج قبل قليل قضية تاريخية تتعلق بالفلسفة اليونانية وسبب نشأتحا

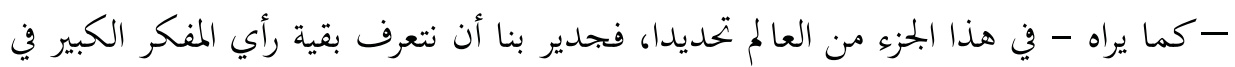

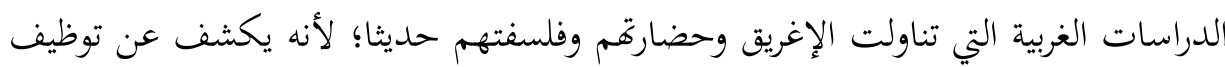
غربي غير علمي للبحث والدرس الأكاديمي، وهو أمر له خطورته الكبرى على العلم والفكر والحياة الإنسانية عموما.

يرى العقاد أن الأمة اليونانية لها تاريخ حقيقي، وآخر ليس كذلك تم توظيفه في تسويق

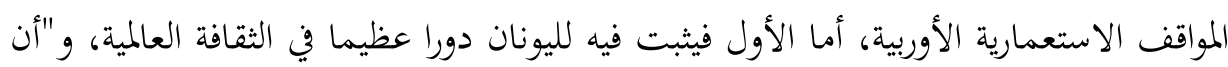
نصيبها في هذه الثقافة لا يعلوه نصيب، ولا حاجة بها معه إلى انتحال الدعوى واغتصاب الفخار بغير دليل. وحسبها أغا أخرجت للعالم سقراط وأفلاطون وأرسطو في ثلاثة أجيال

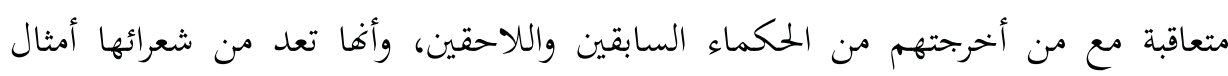
هوميروس ويوربيدس واسكايلاس وسفوكليس وأرستوفان، ومن علمائها ومؤرخيها ذلك الطراز

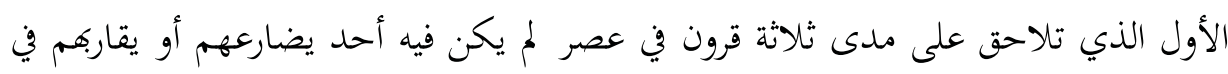

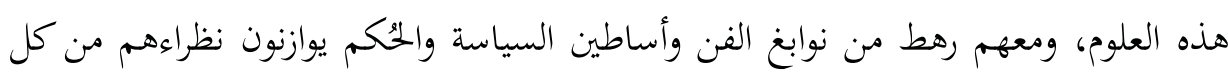

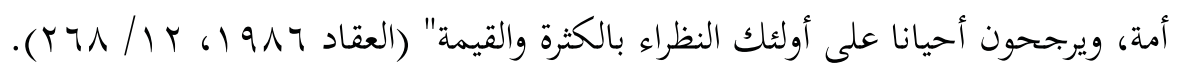

DINIKA, Volume I, Number 3, September - December 2016 
وأما التاريخ الموجَّه والمصنوع لليونان في رأي العقاد، فهو القائم على التهويل وإثبات

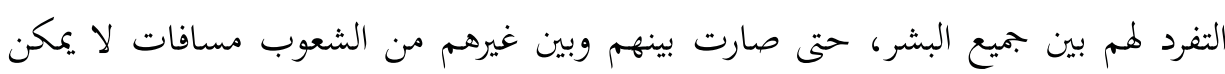

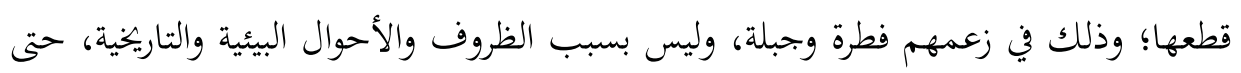

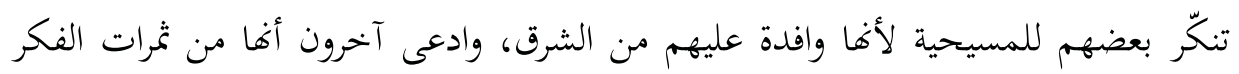

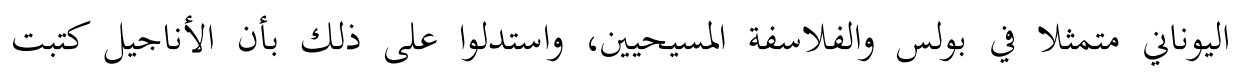

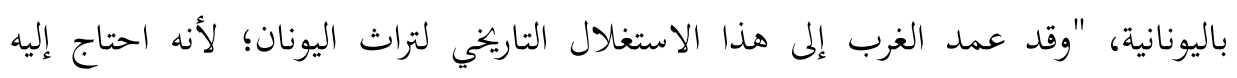

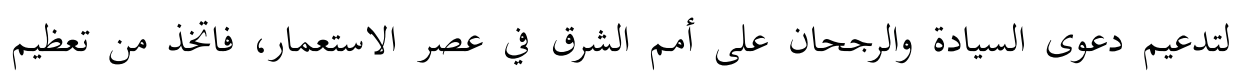

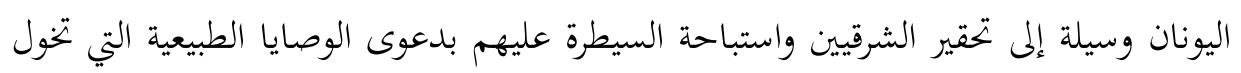

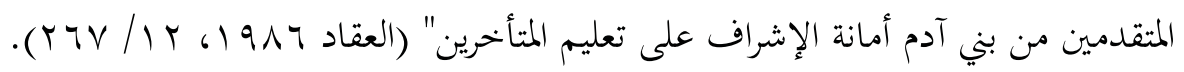

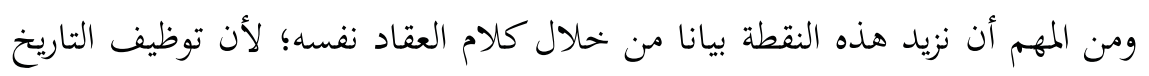

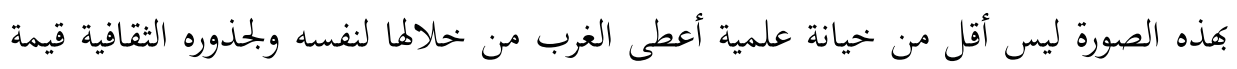

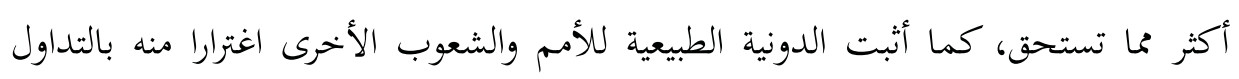

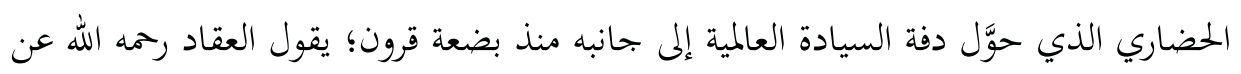

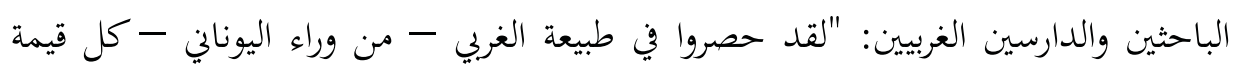

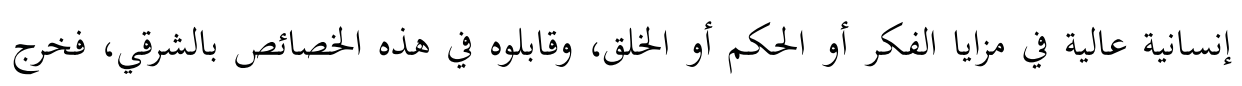

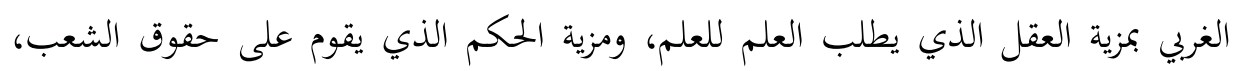

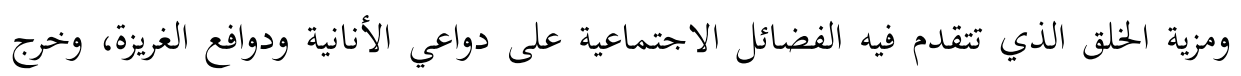

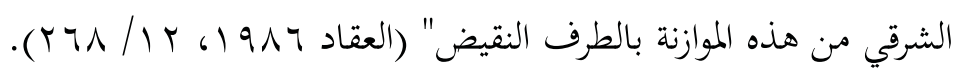

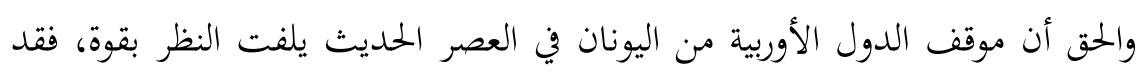

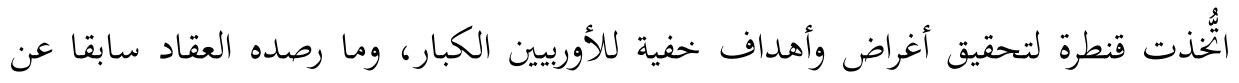

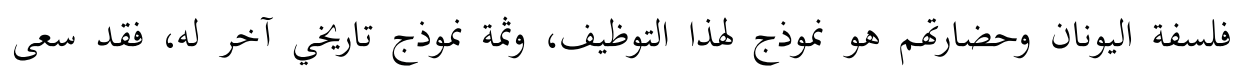


الأوربيون في عشرينيات القرن التاسع عشر إلى تحقيق أهدافهم الاستعمارية ضد الدولة

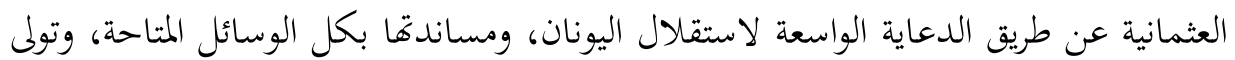

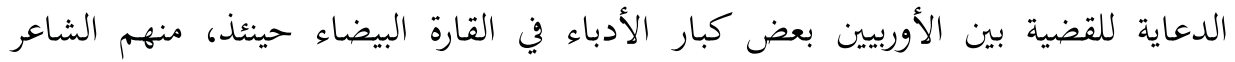

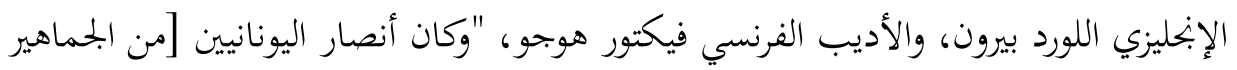

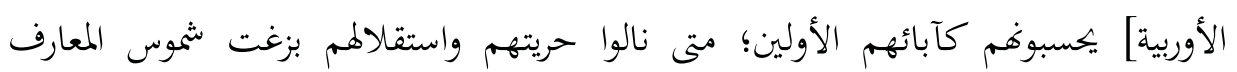

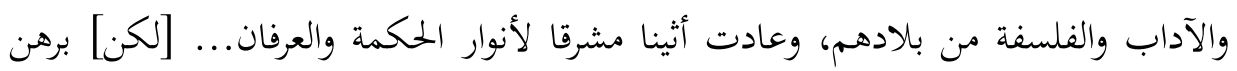

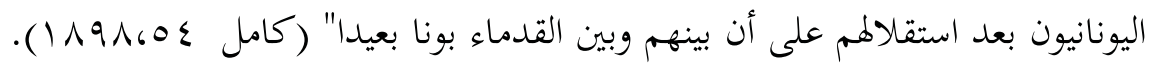

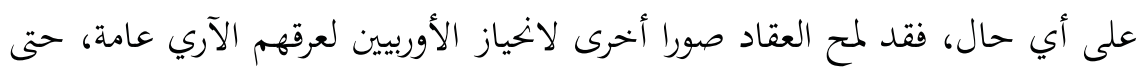

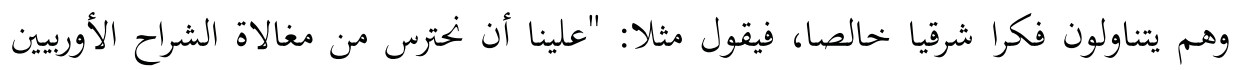
كذذه الفلسفة البوذية؛ لأغم يتعصبون لكل منسوب إلى الآرية على اعتبارها عنصر الأوربيين.

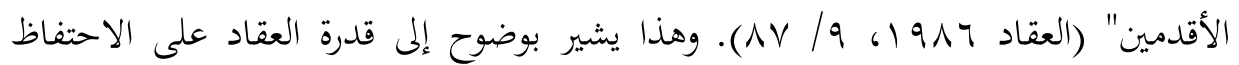

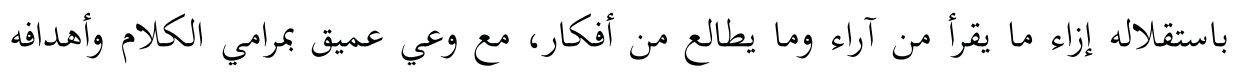

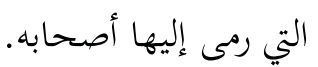

\section{أصالة الفلسفة الإسلامية}

ومن القضايا المهمة التي عرض لها العقاد مما يتعلق بالفلسفة اليونانية، مدى أصالة

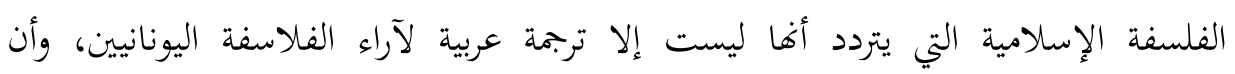

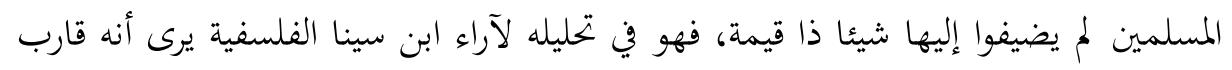

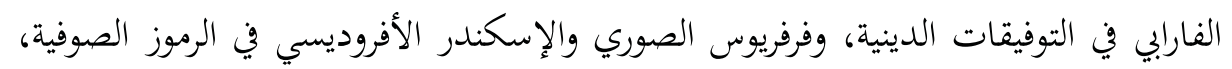

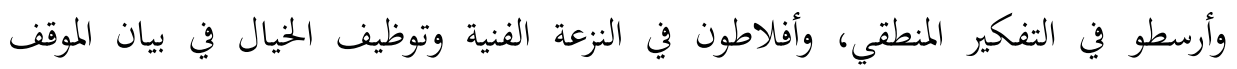

DINIKA, Volume I, Number 3, September - December 2016 
الفلسفي، إلا أنه يعقب على ذلك بقوله: "ولا يدل هذا على أنه كان متقيدًا بمذهب أستاذ

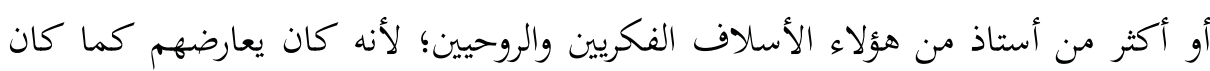
يجاريهم ويوافقهم، وكانت أكثر معارضاته لهم فيما بينهم وبين الدين من خلاف، فلم يكن يكن

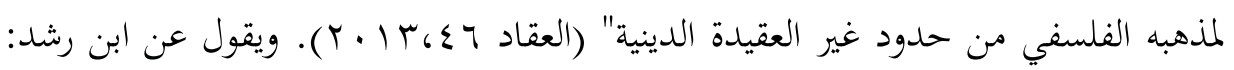

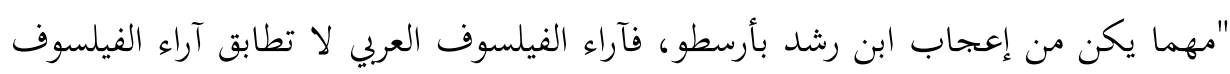

$$
\text { الإغريقي في كل شيء" (العقاد ب.ت، ، •ب). }
$$

وهذا يعني أن العقاد كان من المدافعين عن أصالة الفلسفة الإسلامية وإنتاج الفلاسفة

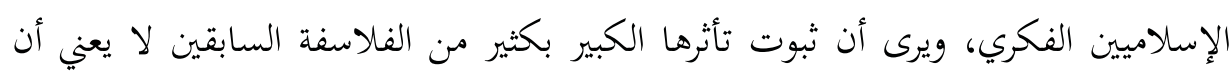
ننزع عنها الأصالة التي بدت بالنسبة لابن سينا مثلا في التزامه بحدود العقيدة الإسلامية -

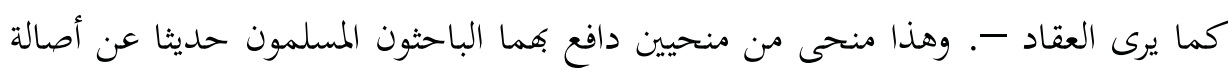
إنتاج أسلافهم العقلي والفلسفي، ففي حين أثبت بعض الباحثين شيئا من الأصالة والاستقلالية لمتفلسفة الإسلاميين، فإن هناك من بحث عن أصالة التفكير الفلسفي الإسلامي إني في مجالات أخرى، مثل: علم الكلام، وأصول الفقه. وقد يكون هذا الموقف الذي اختاره العقاد نوعا من التسامح الفكري، وامتد هذا إلى ولى حكمه على مدى موافقة الفلاسفة الإسلاميين للإسلام، فقال عن أبي نصر الفارابي مثلا: "والذي اتفق عليه جلة الثقات أن فلسفة الفارابي فلسفة إسلامية لا غبار عليها، فلم ير فيها جمهرة المسلمين المعنيين بالبحث الفكري حرجًا ولا موضع ريبة، ولا نخالها تغضب متدينًا

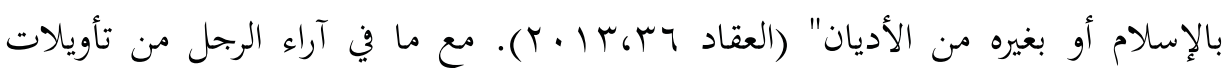

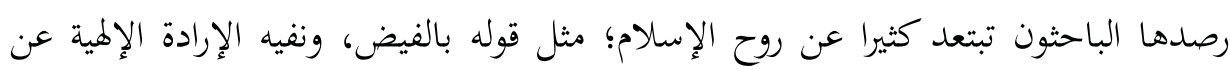
وجود العالم، وإثبات الأزلية للوجود، وتفضيل الفيلسوف على النبي، وغير ذلك. لئكل 


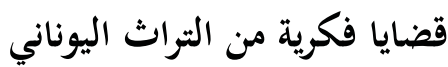

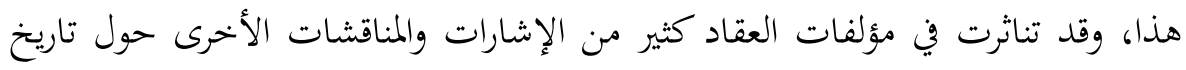

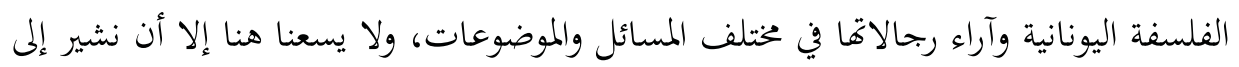
بعضها باختصار، ومن أمثلة ذلك ما يلي: أ) قدم لنا ملخصا متثازا للآراء الفلسفية لكبار الفلاسفة اليونانيين في سياق طويل (العقاد

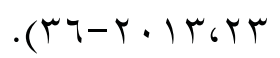

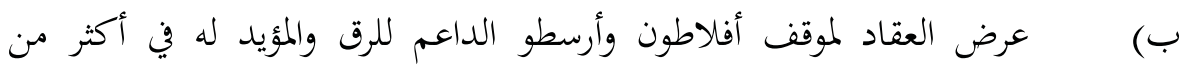

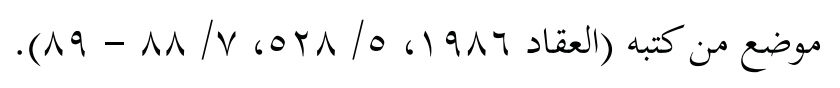

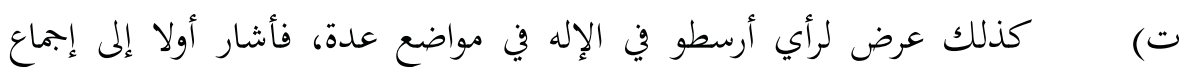

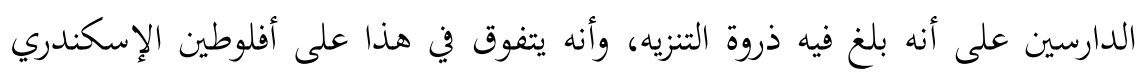

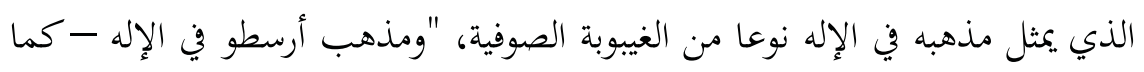

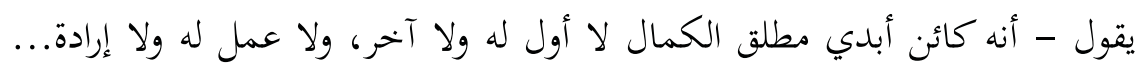

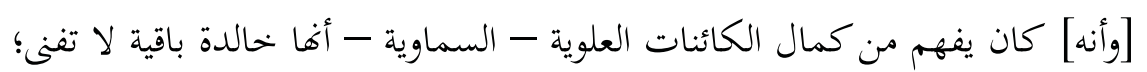

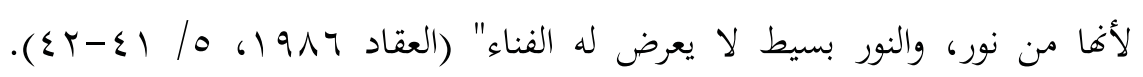

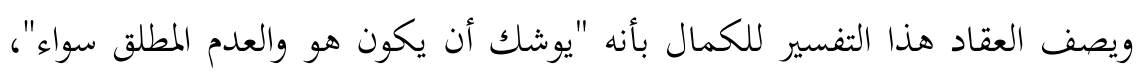

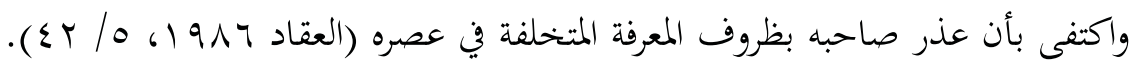

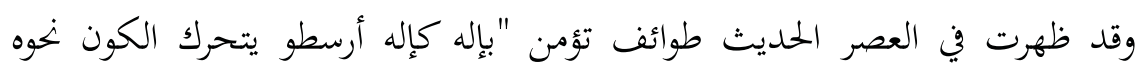

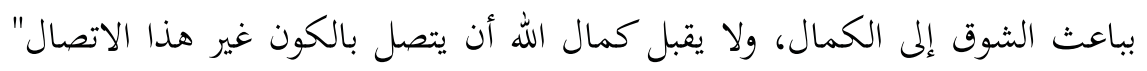

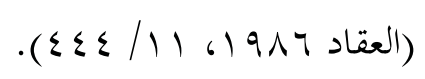

ج) كما تناول العقاد بالعرض والمناقشة نظرية أرسطو في الأخلاق، وإن كان نسبها

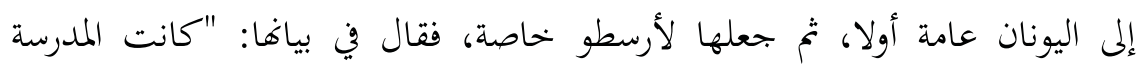

DINIKA, Volume I, Number 3, September - December 2016 
اليونانية تعتبر الأخلاق الفاضلة وسطا بين طرفين، أو تحث طالب الفضيلة على

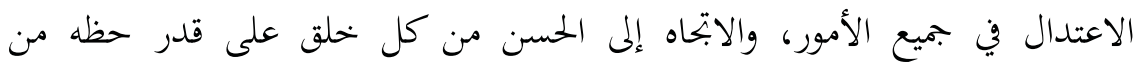
الاعتدال، فالشجاعة وسط بين التهور والجبن، والكرم وسط بين الإسراف والبخل...

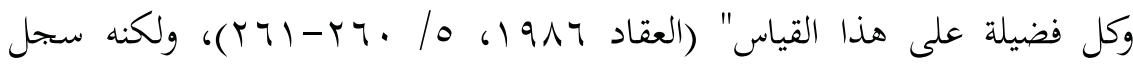
ملاحظاته عليها في ثلاث صفحات كوامل، وأهمها أغا تعتمد على "مقياس للأخحلاق شبيه بمقاييس الهندسة والحساب بعيد عن تقدير العوامل النفسية والقيم الروحية في

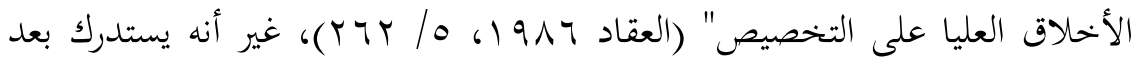

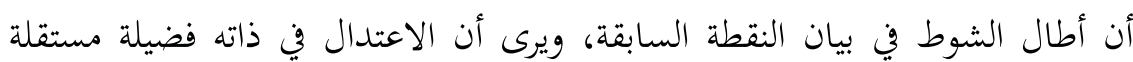

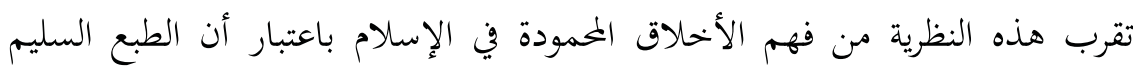

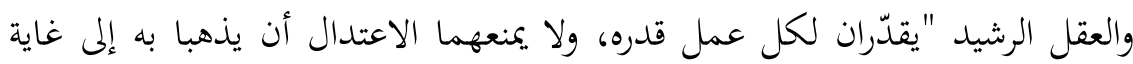

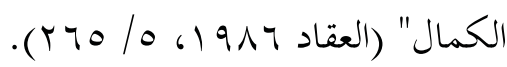

د) كما عرض العقاد وأطنب في بيان موقف اليونان من القدر، وميز في هذا بين رؤيتهم للقدر من منظار الدين والأسطورة ورؤيتهم له من زاوية الفلسفة، فأما الدين

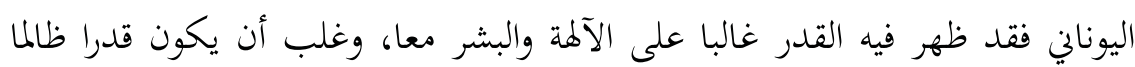

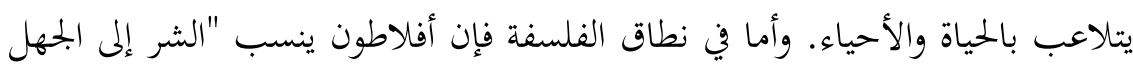
وقلة المعرفة، ويرى أن الإنسان لا يختار الشر وهو يعرفه... ولكنه لا يساق إليه بتقدير الآلهة؛ لأن الآلة خير لا يصدر عنها إلا الخير ... فالشر موجود في هذا العالمالم، ولكنه

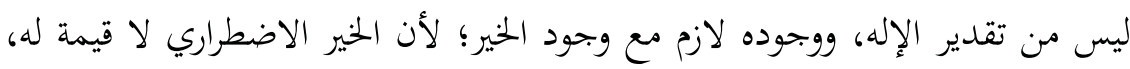

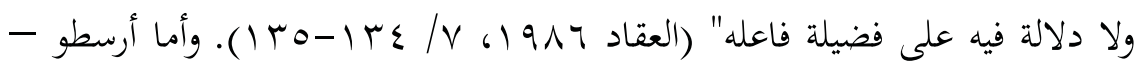
كما يسجل العقاد عنه - فإن مذهبه في القدر يناسب رأيه في الإله نفسه كما سبق،

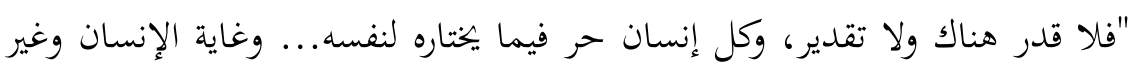


الإنسان من هذه الكائنات أن تحقق ما ينبغي لوجودها على الوجه الذي يناسب ذلك

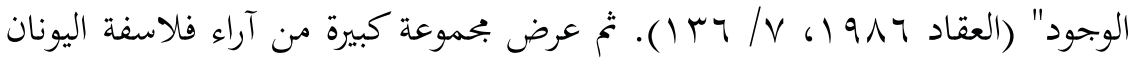
في القدر، مثل: ديمقريطس، وهرقليطس، وفيثاغوراس، وزينون والرواقيين، وأفلوطين، وغيرهم. هـ) كما عرض العقاد للتشابه بين دين الصابئة وآراء فلاسفة اليونان، فأقوال الصابئة في تنزيه الإله - كما يسجل - تتشابه مع أقوال الفلاسفة، وهم يحرمون أنواعا من الطعام بعضها يشبه ما حرمه الفيثاغوريون. وطريق هذا التأثير المتوقع هو قسس لإكس النساطرة الذين فروا إلى جنوب العراق هربا من الاضطهاد في بدايات المسيحية، وكانت

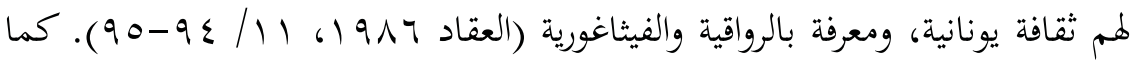
أطال العقاد - وهو يحاول بيان الحالة الثقافية في أرض الجليل التي شهدت ميلاد المسيح عليه السلام - في بيان آراء ومواقف الفيثاغوريين والرواقيين والأبيقوريين وتأثيرهم

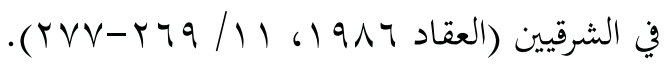

وحتى لا يكون الاستقصاء في بيان المواضع والموضوعات التي تعرض لها العقاد في كتبه خاصة

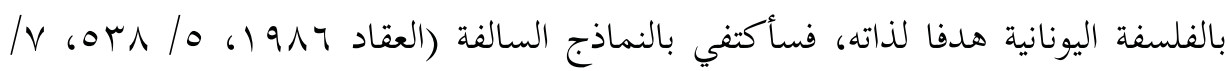

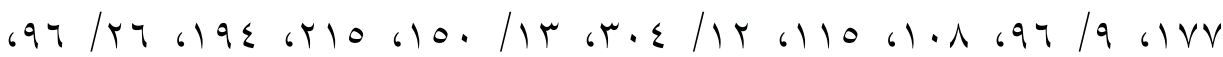
ع r.)، بل أكتفي بهذا القدر من الدراسة، وأترك المحال لنتائجها التي يمكن استخلاصها من المبحثين السابقين.

DINIKA, Volume I, Number 3, September - December 2016 


\section{خاتمة}

حاولت في السطور السابقة بيان الآراء والمواقف الفكرية التي اتخذها كل من العقاد وطه

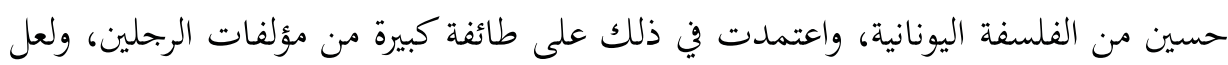
أهم النتائج التي يمكن استخلاصها من المبحثين اللذين تضمنتهما الدراسة تتلخض فيما يلي: أ) يحمل كل من طه حسين والعقاد نظرة تقدير واحترام للإنتاج الثقافي اليوناني، ويعتبر انه

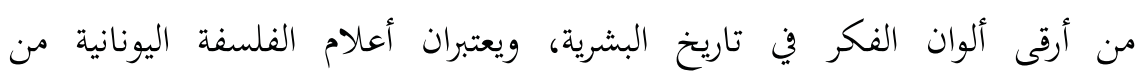
الشخصيات الأهم في تاريخ الفكر البشري.

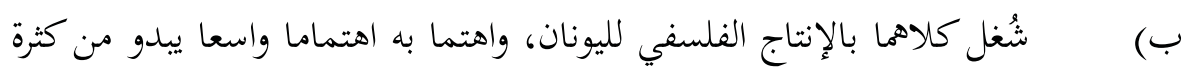
حديثهما عن أفكار الفلاسفة اليونانيين ووقائع حياةم في جملة كبيرة من كتبهما. ج) اكتفى العقاد بالحديث عن الفلاسفة اليونانيين وأفكارهم في كتب مؤلفة لموضوعات أخرى، في حين أضاف طه حسين إلى ذلك ترجمة بعض الإنتاج الثقافي اليوناني السياسي

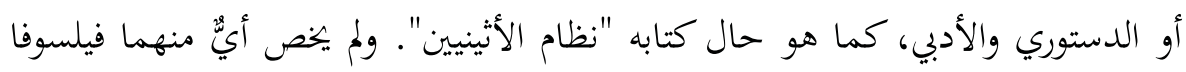
يونانيا أو فكرة فلسفية يونانية أو بحمل الفلسفة اليونانية بكتاب لا يتجاوزها.

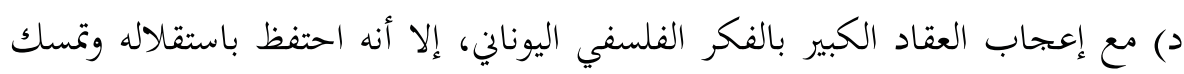
بهويته الثقافية العربية الإسلامية في مواجهته، وكذلك انتقد بقوة الطريقة التي درس بها

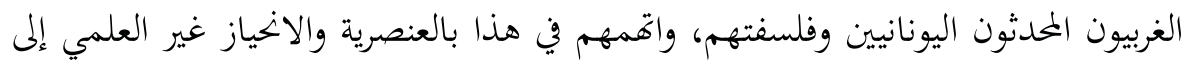

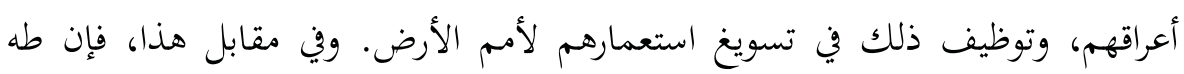

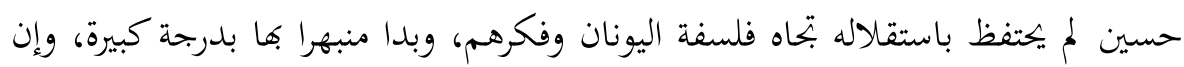
كان موقفه قد تطور فيما بعد نوعا ما.

هـ) غلب على طه حسين عرض أفكار اليونانيين عرضا بسيطا، وأضاف العقاد إلى عرضها نقدها وتقييمها في أغلب الأحيان. 


\section{المصادر والمراجع}

1. أرسطوطاليس. ع ا. r. نظام الأثينيين. ترجمة: طه حسين. القاهرة: مؤسسة هنداوي للتعليم والثقافة.

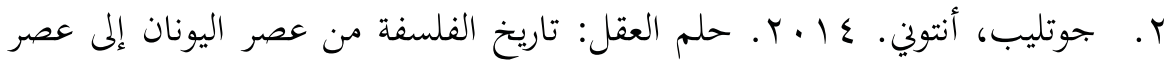
النهضة، ترجمة: محمد طلبة نصار. القاهرة: مؤسسة هنداوي للتعليم والثقافة. r. حسين، طه. r ا • r. نقد وإصلاح. القاهرة: مؤسسة هنداوي للتعليم والثقافة.

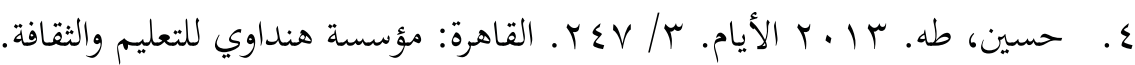
ه. حسين، طه. ب ا • ץ. ألوان. القاهرة: مؤسسة هنداوي للتعليم والثقافة.

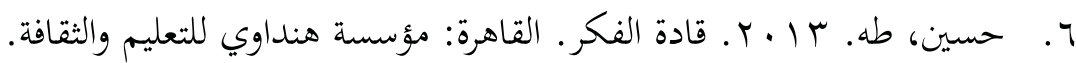
V. حسين، طه. r ا • r. من بعيد. القاهرة: مؤسسة هنداوي للتعليم والثقافة. م. حسين، طه. r ا ـ r. من لغو الصيف. القاهرة: مؤسسة هنداوي للتعليم والثقافة. 9. حسين، طه. ع ا • r. مستقبل الثقافة في مصر. القاهرة: مؤسسة هنداوي للتعليم والثقافة.

• 1 ـرسل، برترندز. r1911. حكمة الغرب: عرض تاريخي للفلسفة الغربية في إطارها

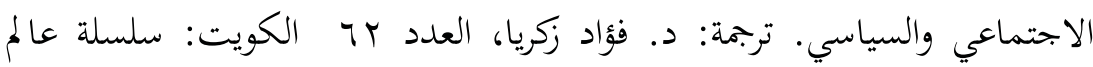

المعرفة.

1 ا ـ الشافعي، حسن محمود. 1 . . r. فصول في التصوف. القاهرة: دار البصائر. r ا ـ العقاد. r ا ـ r. ابن سينا. القاهرة: مؤسسة هنداوي للتعليم والثقافة. r ا ـ العقاد. r ا ـ ץ. ابن الرومي. القاهرة: مؤسسة هنداوي للتعليم والثقافة. ع اـ العقاد. س ا ـ r. الثقافة العربية. القاهرة: مؤسسة هنداوي للتعليم والثقافة.

DINIKA, Volume I, Number 3, September - December 2016 


$$
\begin{aligned}
& \text { ه } 1 \text {. العقاد. إبليس (الأعمال الكاملة). } \\
& \text { 1 } 1 \text {. العقاد. أبو الأنبياء (الأعمال الكاملة). } \\
& \text { IV } \\
& \text { 11. العقاد. الديمقراطية في الإسلام (الأعمال الكاملة). } \\
& 9 \text { 1 ا ـ العقاد. الفلسفة القرآنية (الأعمال الكاملة). } \\
& \text {. r. العقاد. الله (الأعمال الكاملة). } \\
& \text { اب ا. العقاد. المسيح (الأعمال الكاملة). } \\
& \text { r r . العقاد. ب. ت. ابن رشد: سلسلة نوابغ الفكر العربي. القاهرة: دار المعارف. } \\
& \text { r r. العقاد. حقائق الإسلام (الأعمال الكاملة) } \\
& \text { ع r. العقاد. خحلاصة اليومية (الأعمال الكاملة). } \\
& \text { ه ه . العقاد. عقائد المفكرين (الأعمال الكاملة). }
\end{aligned}
$$

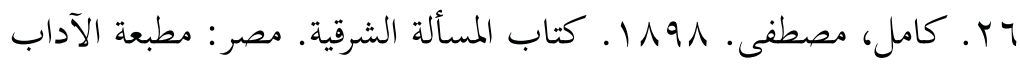

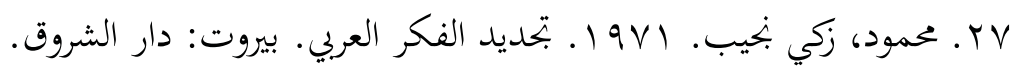


DINIKA, Volume I, Number 3, September - December 2016 